\title{
Characterization of DuPont 9015, Aqueous Processable Dry Film Photoresist for Printed Wiring Boards
}

Kansas City Division

Steve Goldammer

KCP-613-5537

Published April 1995

Topical Report

David Fogleman, Project Leader

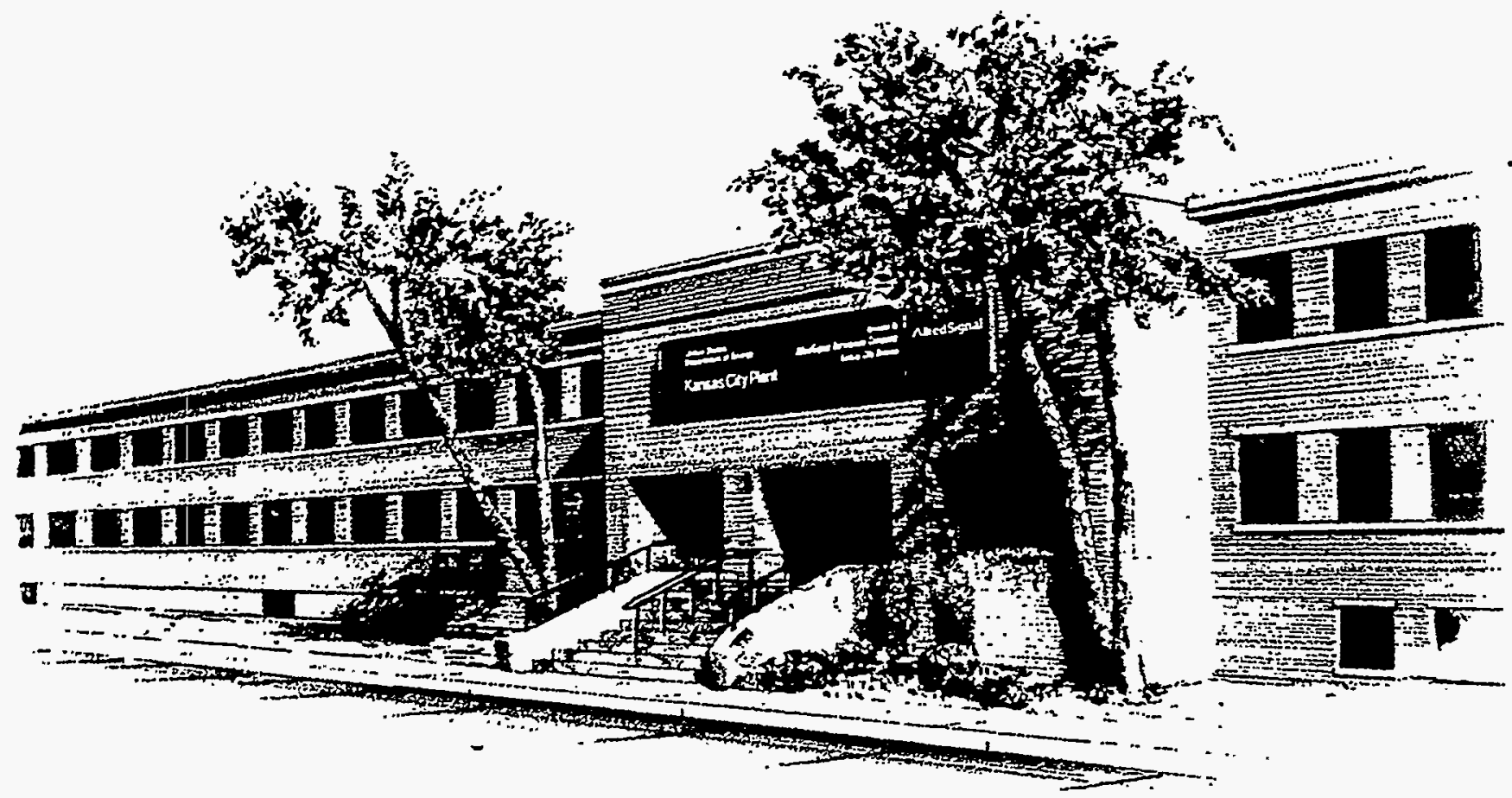

Prepared Under Contract Number DE-ACO4-76-DP00613 for the United States Department of Energy

AlliedSignal

A E R O S PACE 


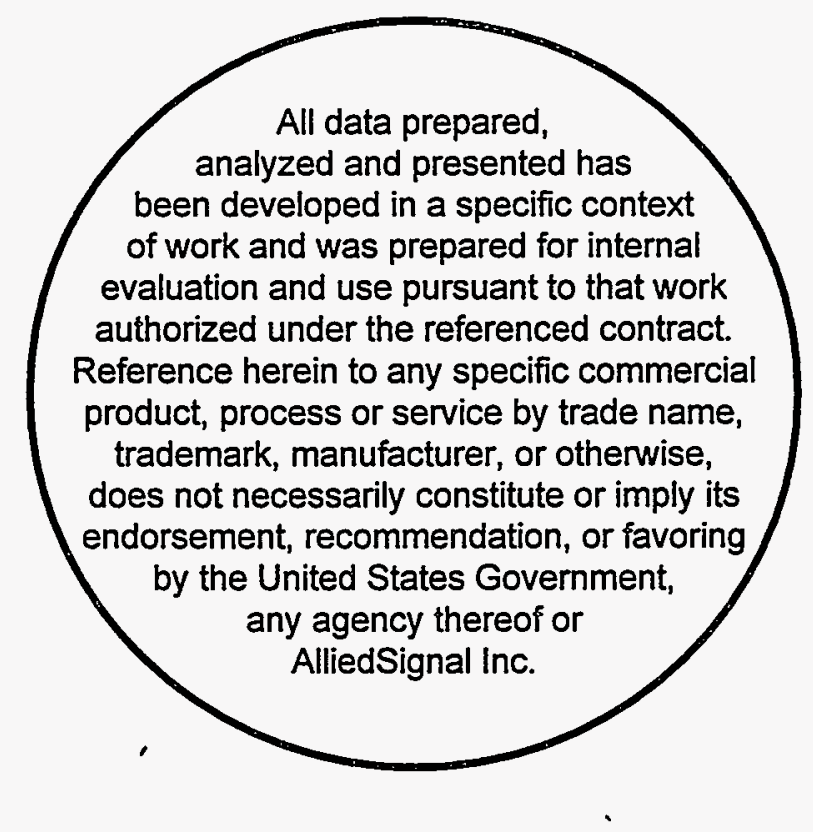

DISCLAIMER

This report was prepared as an account of work sponsored by an agency of the United States Government. Neither the United States Government nor any agency thereof, nor any of their : employees, makes any warranty, express or implied, or assumes any legal liability or responsibility for the accuracy, completeness, or usefulness of any information, apparatus, product, or process disclosed, or represents that its use would not infringe privately owned rights. Refer- ence herein to any specific commercial product, process, or service by trade name, trademark, manufacturer, or otherwise does not necessarily constitute or imply its endorsement, recommendation, or favoring by the United States Government or any agency thereof. The views and opinions of authors expressed herein do not necessarily state or reflect those of the United States Government or any agency thereof.

.3

A prime contractor with the United States

AlliedSignal Inc. Department of Energy under Contract Number Kansas City Division DE-ACO4-76-DP00613.

P. O. Box 419159

Kansas City, Missouri 64141-6159 


\section{DISCLAIMER}

Portions of this document may be illegible in electronic image products. Images are produced from the best available original document. 
Characterization of DuPont 9015 Aqueous Processable Dry Film Photoresist for Printed Wiring Boards

Steve Goldammer

KCP-613-5537

Published April 1995

Topical Report

David Fogleman, Project Leader

Project Team:

Steve Goldammer

John Grice

Tammy Kempf

Carol Krska

Mike McHenry

Don Tucker 
$\ldots+\cdots$ 


\section{Contents}

Section

Page

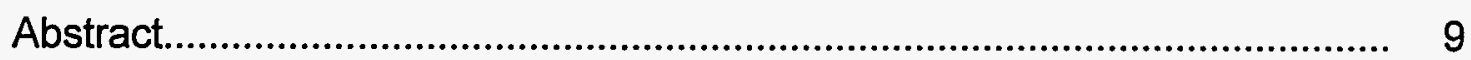

Summary ................................................................................. 9

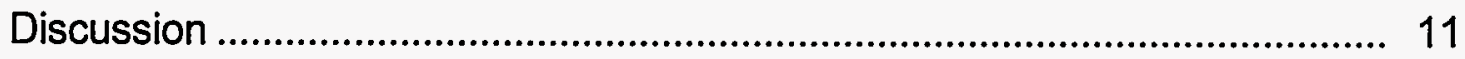

Scope and Purpose .................................................................... 11

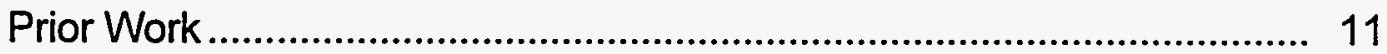

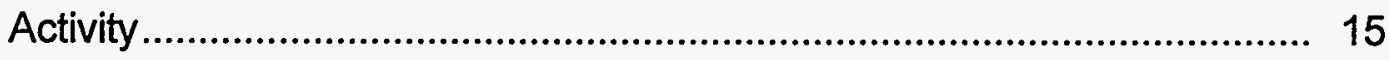

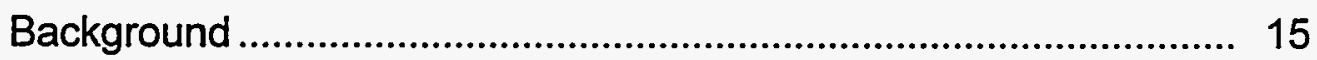

Characterization ................................................................... 15

Future Work ......................................................................... 42

Appendices

A. Group 1 Panels ................................................................. 43

B. Group 2 Panels .................................................................. 47

C. Group 3 Panels ................................................................... 53

D. Group 4 Panels ................................................................. 59

E. Group 5 Panels ................................................................... 65

F. Group 6 Panels.................................................................... 71 

............ 


\section{Illustrations}

Figure

page

1 SEM Photomicrographs of DuPont 4615 Photoresist..................................... 11

2 SEM Photomicrographs of Dynachem HY Photoresist .................................. 12

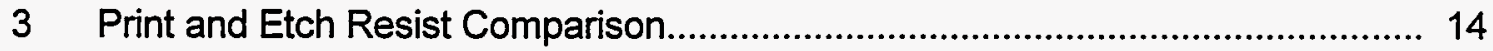

4 Capability Panel Line/Space Snake Pattern (Coupon C) ................................ 17

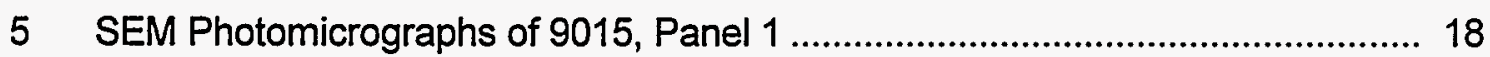

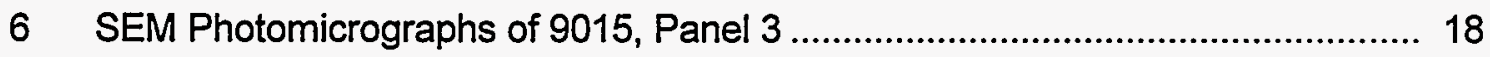

7 SEM Photomicrograph of DuPont Riston 9015, Panel 5............................... 19

8 SEM Photomicrograph of DuPont Riston 9015, Panel 7 ................................ 19

9 SEM Photomicrograph of DuPont Riston 9015, Panel 9............................... 20

10 SEM Photomicrograph of DuPont Riston 9015, Panel 11 .............................. 20

11 SEM Photomicrograph of DuPont Riston 9015, Panel 13.............................. 21

12 SEM Photomicrograph of DuPont Riston 9015, Panel 15 ........................... 21

13 DuPont's Riston 9015 Photoresist with Gold Plating, Front View....................... 23

14 DuPont's Riston 9015 Photoresist with Tin/Lead Plating, Back View................. 24

15 Close Up of 15-Hole Test Coupons and Land/Spacing Coupon ........................ 25

16 Close Up of Line/Space (Serpentine) Pattern .............................................. 26

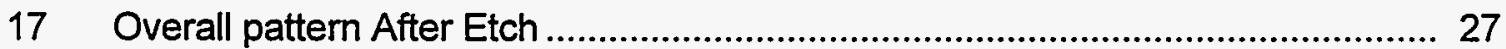

18 Close Up of 15-Hole coupon and Land/Line Spacing Coupon After Etch ............ 28

19 Line/Space Pattern After Etch ................................................................ 29

20 SEM Photomicrograph of Copper Circuit Sidewall, With the Tin-Lead Stripped After Etch ................................................................................... 30

21 DuPont's Riston 9015 Photoresist with Gold Plating, Front View....................... 32

22 DuPont's Riston 9015 Photoresist with Gold Plating, Back View ........................ 33 
23 Close Up of 15-Hole Coupons and Land/Line Spacing Coupon ....................... 34

24 Close Up of Line and Space Serpentine pattern ...................................... 35

25 Overall Pattern After Etch.................................................................. 36

26 Close Up of 15-Hole Coupon and Land and Line Spacing Coupon After Etch .... 37

27 Serpentine Pattern After Etch............................................................. 38

28 SEM Microphotography of Circuit Processed with DuPont Riston 9015, 2-mil Line Cross Section...................................................................... 39

29 SEM Photomicrographs of Circuits Processed with DuPont Riston 9015, Gold-Plated Circuit AFter Etch 40 


\section{Tables}

Number $\quad \cdot \quad$ page

1 Hot Roll laminating of Photoresist............................................................... 15

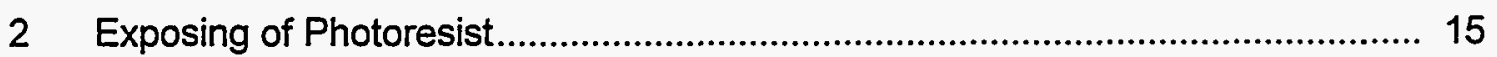

3 Conveyorized Develop of Photoresist ........................................................ 15

4 Designed Experiment for Maximum Line/Space Definition, DuPont 9015 ......... 16

5 Coupon C, Line/Space Snake Pattern....................................................... 16

6 Copper/Tin-Lead panels and Processing Conditions .................................... 22

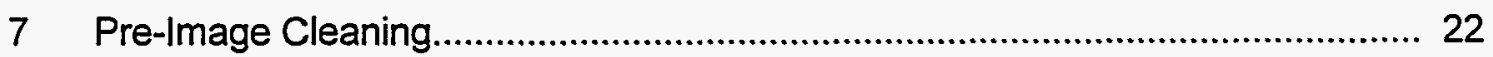

8 Specific Panel Numbers and Processing Conditions for Gold........................... 31

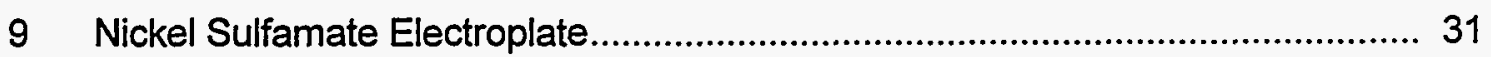

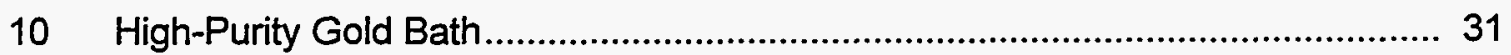

11 Processing Conditions and Yield Response................................................. 41

12 Defects for Various Processing Conditions ............................................ 41

13 Alkaline Etch, Ammoniacal Copper Chloride ............................................... 42

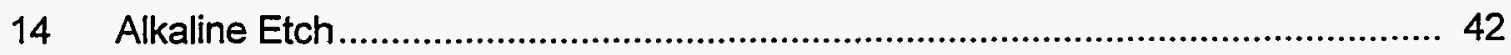





\begin{abstract}
This report describes the evaluation of DuPont's Riston 9015, fully aqueous processable dry film photoresist as a mask for gold plating, tin/lead plating, and print and etch patterning for printed circuit board products.
\end{abstract}

\title{
Summary
}

DuPont's Riston 9015, a fully aqueous processable dry film photoresist, was characterized for use on printed circuit products as a mask for gold plated features. The characterization was performed to replace Dynachem's Laminar HY which was no longer manufactured by Morton Thiokol,Inc., Dynachem Division. Additional work was done to evaluate 9015 as a mask for tin/lead plated patterns and as a mask during alkaline copper etching.

The DuPont 9015 proved to be chemically resistant to the existing copper electroplate, tin-lead electroplate, gold electroplate and alkaline etch processes and produced an etched circuit maintaining 2 mil line and a 5 mil space patterns. 


\section{Discussion}

\section{Scope and Purpose}

The purpose of this evaluation was two-fold:

1. To find a replacement for the Dynachem "HY" dry film photoresist used for selected gold plating on printed circuit board product. A replacement was necessary because Dynachem's HY was no longer going to be available.

2. To have the capability of defining 2-mil line and spaces on the final circuit. Additional work was done to determine if the DuPont 9000 series dry film photoresist could be used for tin-lead patterning or print and etch using alkaline etchant.

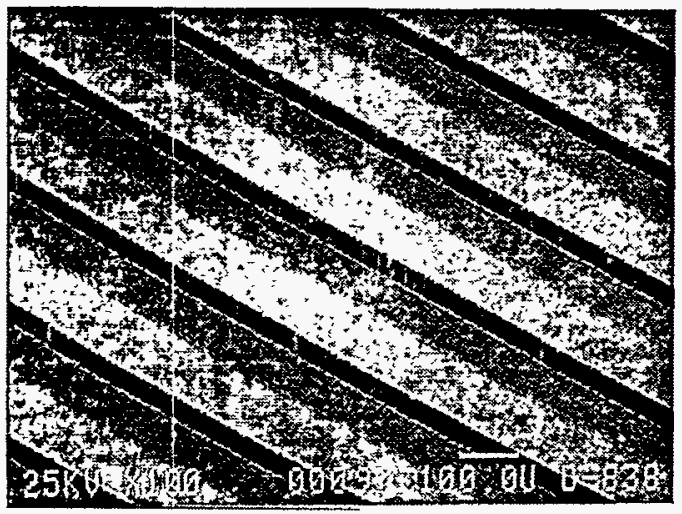

\section{Prior Work}

DuPont's 4615 and Dynachem's HY were originally compared for gold plating capability. The two performance criteria used were adhesion of the dry film photoresist to copper or nickel substrates during the gold plating process and the ability to resolve patterns of 5-mil lines and spaces.

\section{Attributes of DuPont 4615 and Dynachem} HY:

1. Sidewall integrity: This was analyzed by viewing Scanning Electron Microscope (SEM) photomicrographs of 4615 and $\mathrm{HY}$ to determine which photoresist had the straightest sidewall (see Figures 1 and 2).

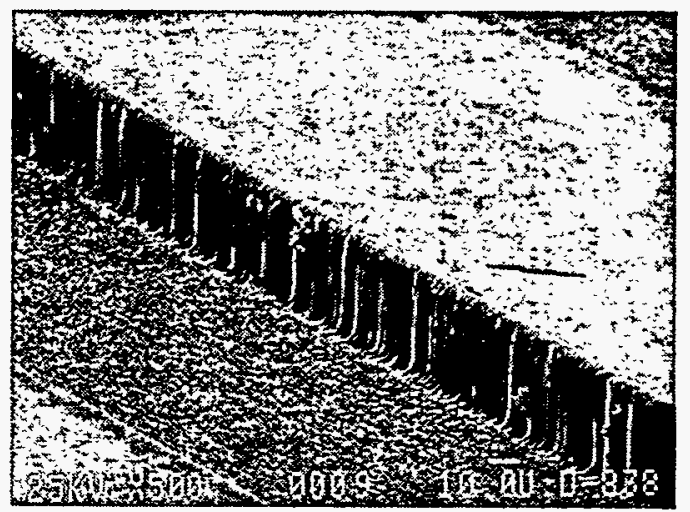

Panel 9, Exposure Setting 80, Stouffer Step 9
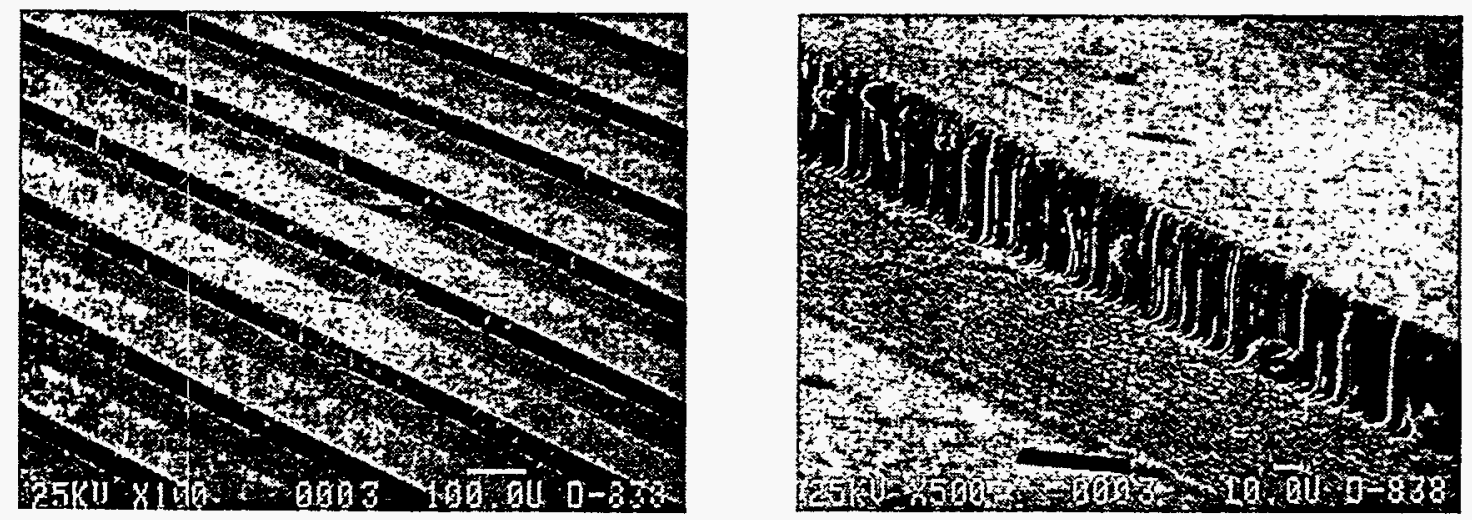

Panel 3, Exposure Setting 80, Stouffer Step 9

Figure 1. SEM Photomicrographs of DuPont 4615 Photoresist 

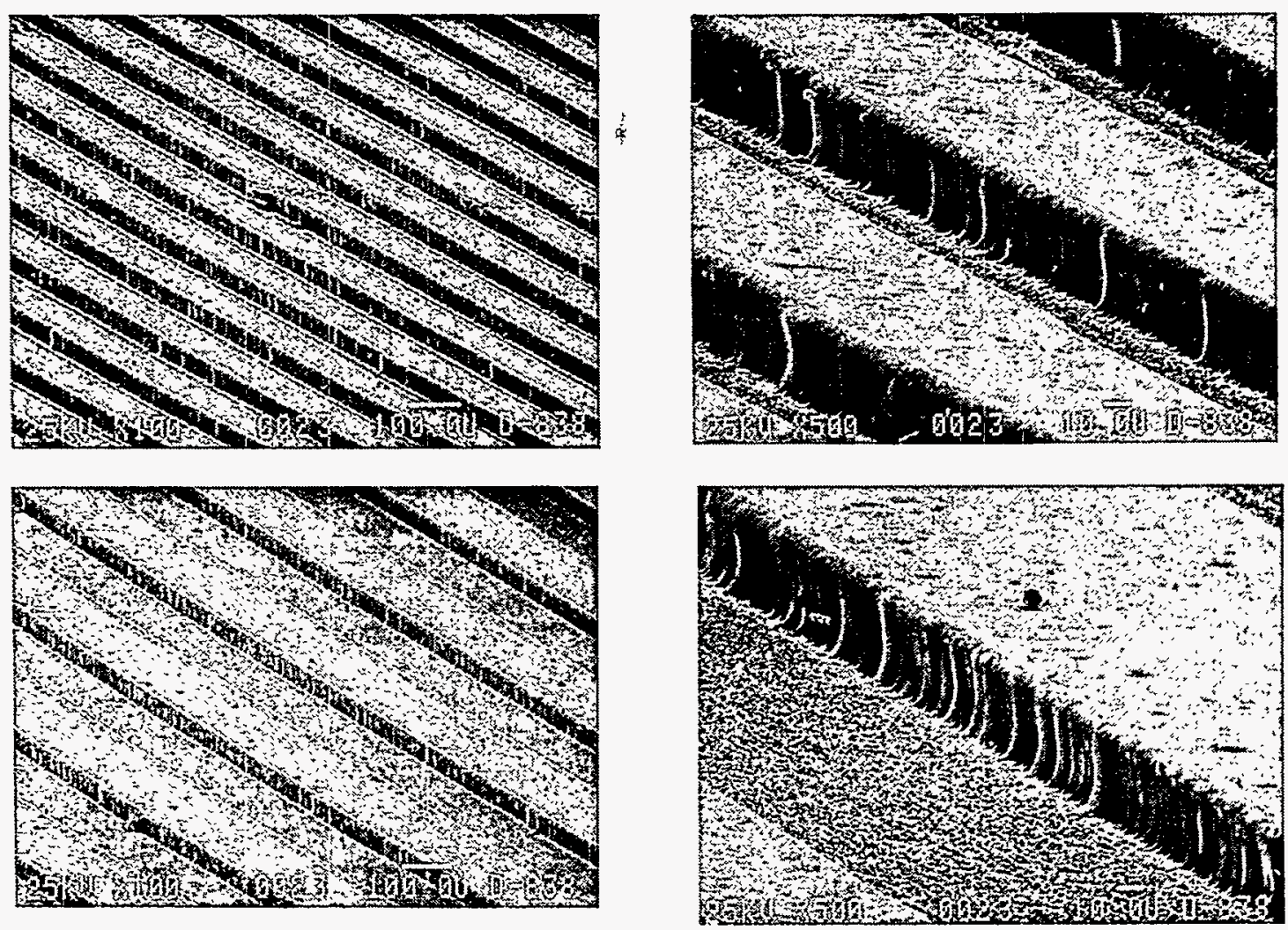

Panel 23, Exposure Setting 50, Stouffer Step 8
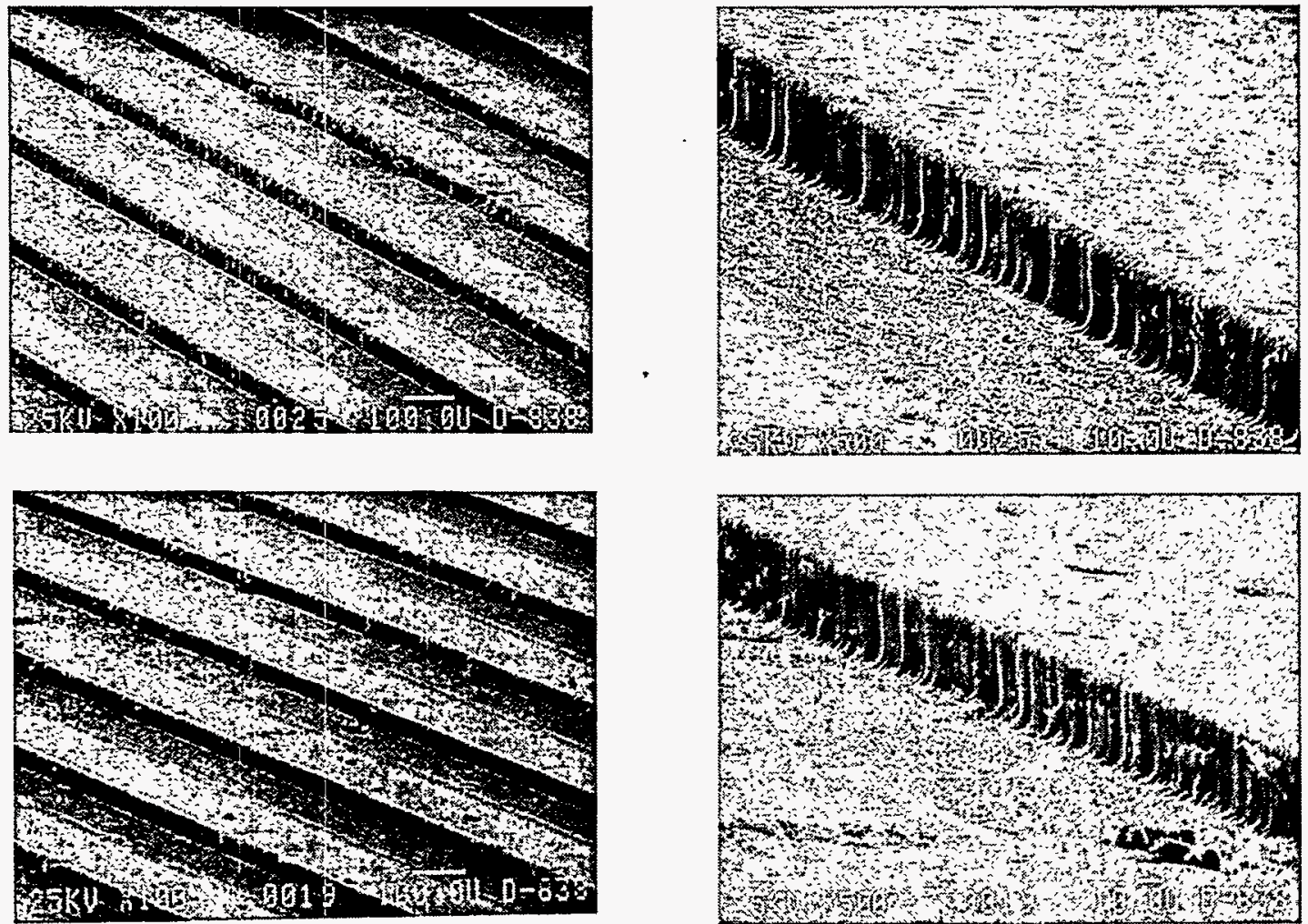

Panel 25, Exposure Setting 70, Stouffer Step 9

Figure 2. SEM Photomicrographs of Dynachem HY Photoresist 
Results: The DuPont's 4615 shows a slightly straighter sidewall in the SEM micrographs

2. Path width: This was data generated by an inspector measuring the widest part of the 5- and 10-mil circuit paths under a microscope at $40 \mathrm{X}$.

Results: The print and etch comparisons of the 5- and 10-mil photoresist paths measurements are shown in Figure 3. Path width measurements for both the DuPont's 4615 and the Dynachem's HY were acceptable.

3. Chemical resistance/adhesion: This evaluation was subjective, looking for resist breakdown, or changes in surface texture or color during all printed circuit board chemical processes. The ability to withstand nickel and gold plating were the most rigorous tests.

Results: The DuPont 4615 occasionally broke down during the nickel and gold plating process. Further evaluations also confirmed the results of the 4615 sporadic resist breakdown. The HY did not show signs of resist breakdown during the same evaluations. Consequently, HY was chosen as the photoresist to image gold plated patterns.

4. Process Latitude: This was a review of the process interactions for photoimaging both resists. The photoimaging parameters were varied during this characterization, which helped establish a processing window for future design reviews.

Results: DuPont's 4615 was more sensitive than the HY to temperature changes during lamination. The HY could be laminated using a wider temperature range which gave $\mathrm{HY}$ a larger processing window for manufacturing.

Process sequence used:

1. Pre-image conveyorized chemical cleaning

2. Hot roll laminating of photoresist on copper or nickel substrate (Table 1)

3. Exposing of photoresist (Table 2)

4. Conveyorized developing of photoresist (Table 3)

5. Pre-plate cleaning (acid detergent cleaner dip tank)

6. Water rinse

7. Ammonium persulfate (microetching of copper in dip tank)

8. Water rinse

9. Nickel strike

10. Water rinse

11. Gold plate

12. Water rinse

The specific photoimaging parameters for both resists are shown in Tables 1 - 3.

As a result of this evaluation, HY was chosen for gold patterning. DuPont 4615 was chosen for the print and alkaline etch process. 


\section{PRINT AND ETCH RESIST COMPARISON \\ DYNACHEM HY VS DUPONT 4615 \\ CONDUCTOR MIDTH AFTER DEVELOPING}

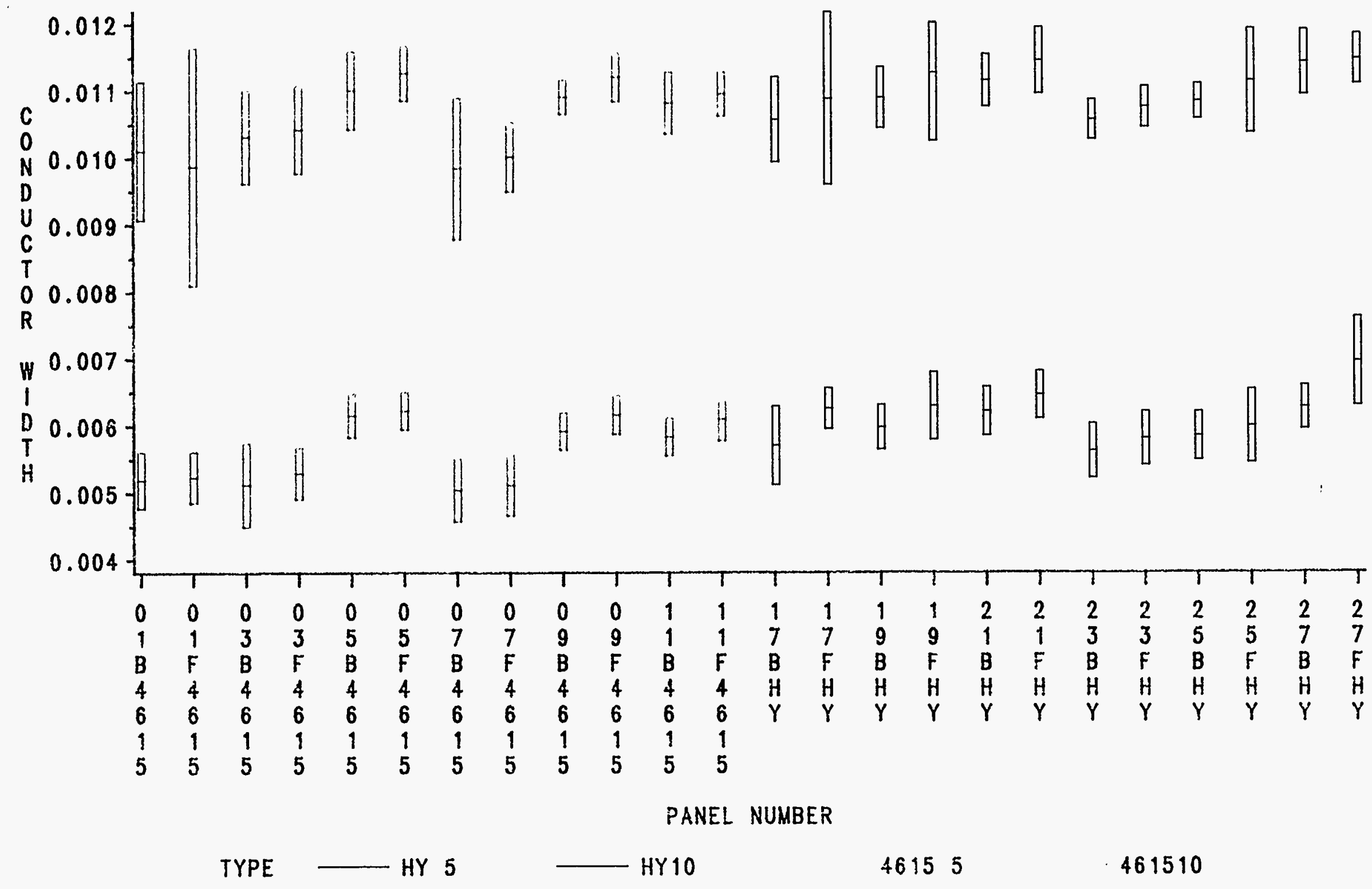


Table 1. Hot Roll Laminating of Photoresist

\begin{tabular}{|c|c|c|}
\hline \multicolumn{3}{|c|}{$\begin{array}{l}\text { DuPont HRL Hot Roll Laminator CE\# } \\
54013 / 59225\end{array}$} \\
\hline Parameters & HY & 4615 \\
\hline Temperature ${ }^{\circ} \mathrm{C}$ & 116 & 100 \\
\hline Exit Board Temperature ${ }^{\circ} \mathrm{F}$ & 148 & 139 \\
\hline Pressure (psi) & 30 & 30 \\
\hline Roll Speed (meters/min) & 1.5 & 1.5 \\
\hline
\end{tabular}

Table 2. Exposing of Photoresist

\begin{tabular}{||c|c|c||}
\hline \multicolumn{3}{|l|}{ Optical Radiation Corporation Optibeam } \\
6000, CE\# 66483 \\
\hline $\begin{array}{l}\text { Stouffer Step } \\
\text { Tablet Reading } \\
\text { (bare copper) }\end{array}$ & $\begin{array}{c}\text { Exposure } \\
\text { Setting } \\
\text { HY }\end{array}$ & $\begin{array}{c}\text { Exposure } \\
\text { Setting } \\
4615\end{array}$ \\
\hline 8 & 50 & 57 \\
\hline 9 & 70 & 80 \\
\hline 10 & 98 & 112 \\
\hline
\end{tabular}

Table 3. Conveyorized Develop of Photoresist

\begin{tabular}{|c|c|c|}
\hline \multicolumn{3}{|c|}{$\begin{array}{l}\text { Advanced Systems Inc. (ASI) Developer, CE\# } \\
64707\end{array}$} \\
\hline Parameters & HY & 4615 \\
\hline Temperature ${ }^{\circ} \mathrm{F}$ & 100 & 85 \\
\hline $\begin{array}{l}\text { Spray pressure } \\
\text { (psi) }\end{array}$ & $22 / 22$ & $21 / 24$ \\
\hline $\begin{array}{l}\text { Conveyor Speed } \\
(\mathrm{ft} / \mathrm{min})\end{array}$ & $\begin{array}{l}\text { 1. } 2.0 \\
\text { 2. } 3.0\end{array}$ & $\begin{array}{l}\text { 1. } 3.0 \\
\text { 2. } 3.75\end{array}$ \\
\hline \multicolumn{3}{|c|}{ Break Point(Dwell Time) } \\
\hline $\begin{array}{l}\text { 1. } 50 \% \\
\text { (3rd spray bar) }\end{array}$ & 1. $1 \mathrm{~min} 50 \mathrm{~s}$ & 1. $1 \mathrm{~min} 13 \mathrm{~s}$ \\
\hline $\begin{array}{l}\text { 2. } 75 \% \\
\text { (4th spray bar) } \\
\end{array}$ & 2. $1 \min 14 \mathrm{~s}$ & 2. $58 \mathrm{~s}$ \\
\hline
\end{tabular}

\section{Activity}

\section{Background}

The use of dry film photoresist for selective gold plating is conventional to the printed circuit board industry. DuPont's Riston 9000 series was relatively new to the commercial market when this study was done.

Companies like AT\&T, IBM, and TI were doing evaluations comparing this dry film photoresist to their existing photoresists and printed circuit board (PCB) fabrication processes. The Kansas City Division chose to evaluate the 9000 photoresist due to the prior information learned from these other companies. The 9000 series photoresists had many different thicknesses, and 9015 was chosen because of its 1.5-mil-thick photoresist. DuPont 9015 gave both good imaging resolution and chemical resistance during the build of copper and tin-lead plating.

DuPont 9015 is marketed as an all-purpose photoresist. This evaluation was expanded to determine the performance not only of gold plating but also copper, tin-lead plating, and alkaline etching. This evaluation was not designed to be a side-by-side comparison to Dynachem's HY photoresist. The remainder of this report concerns the 9015 study only. The data generated in this evaluation was to determine the 9015 capability in the existing processes.

\section{Characterization}

This study was focused on four specific qualifying areas to confirm the 9015 photoresist's adequacy for printed wiring board fabrication in the Kansas City facility.

\section{Photoresist performance}

The photoresist imaging process was characterized by varying the parameters of lamination, total exposure energy, and developing dwell time (as determined by conveyor speed), and evaluating the patterns by scanning electron micrographs. The performance of the photoresist processed at various parameters was evaluated by its ability to maintain a 2-mil path after electroplating or alkaline etching. 
Tin-Lead Plating

The tin-lead plating process was a very good test to demonstrate the chemical resilience of the photoresist and minimum path width capability.

\section{Gold plating}

The nickel and gold plating process was a very rigorous test for photoresist. The chemistries and dwell times in the plating baths made it a very good visual test for photoresist adhesion and chemical resistance.

Alkaline etching

The alkaline etching solution is a very aggressive bath for most fully aqueous photoresists, such as DuPont's 9015. Alkaline solutions, in fact, are used to strip off aqueous photoresists. Resistance to the alkaline etchant also showed how well the photoresist was cured or polymerized during the exposure operation.

\section{Photoresist Imaging Performance}

To expedite the evaluation of the DuPont 9015,16 panels were fabricated. The parameters chosen were lamination temperature, exposure energy, and developing dwell time. Based on past photoresist processing experience, these parameters have the greatest effect on photoresist performance.

Table 4 shows the specific parameters which were varied and the values selected for each.

Table 4. Designed Experiment for MaximumLine/Space Definition, DuPont 9015

\begin{tabular}{||l|c|c|c|c|c|c|c|c||}
\hline \hline Panel & 1,2 & 3,4 & 5,6 & 7,8 & 9,10 & 11,12 & 13,14 & 15,16 \\
\hline Lamination ( $\left.{ }^{\circ} \mathrm{C}\right)$ & 110 & 100 & 110 & 100 & 110 & 100 & 100 & 110 \\
\hline Expose (Setting/Step) & $\begin{array}{c}110 \\
9\end{array}$ & $\begin{array}{c}185 \\
11\end{array}$ & $\begin{array}{c}185 \\
11\end{array}$ & $\begin{array}{c}110 \\
9\end{array}$ & $\begin{array}{c}110 \\
9\end{array}$ & $\begin{array}{c}110 \\
9\end{array}$ & $\begin{array}{c}185 \\
11\end{array}$ & $\begin{array}{c}185 \\
11\end{array}$ \\
\hline Develop (Ft/Min) & 2.5 & 2.0 & 2.5 & 2.5 & 2.5 & 2.5 & 3.25 & 2.5 \\
\hline
\end{tabular}

The test vehicle used to demonstrate the 9015 performance was the multilayer capability panel (1468622-105). Figure 13 shows the overall panel layout. This panel was designed to be used for multiple material evaluations and had test coupons and serpentine patterns containing 2-, 5-, 10-, 15-, and 25-mil lines and spaces as shown in Figure 4 and Table 5.

Table 5. Coupon C, Line/Space Snake Pattern

\begin{tabular}{||l|c|c|c|c|c|c|c|c|c|c||}
\hline Coupon Indicator $\left(\mathrm{C}_{1}\right)$ & 1 & 2 & 3 & 4 & 5 & 6 & 7 & 8 & 9 & 10 \\
\hline Line (mil) & 2 & 2 & 2 & 2 & 5 & 5 & 5 & 10 & 10 & 10 \\
\hline Space (mil) & 2 & 5 & 10 & 15 & 5 & 10 & 15 & 5 & 10 & 15 \\
\hline
\end{tabular}




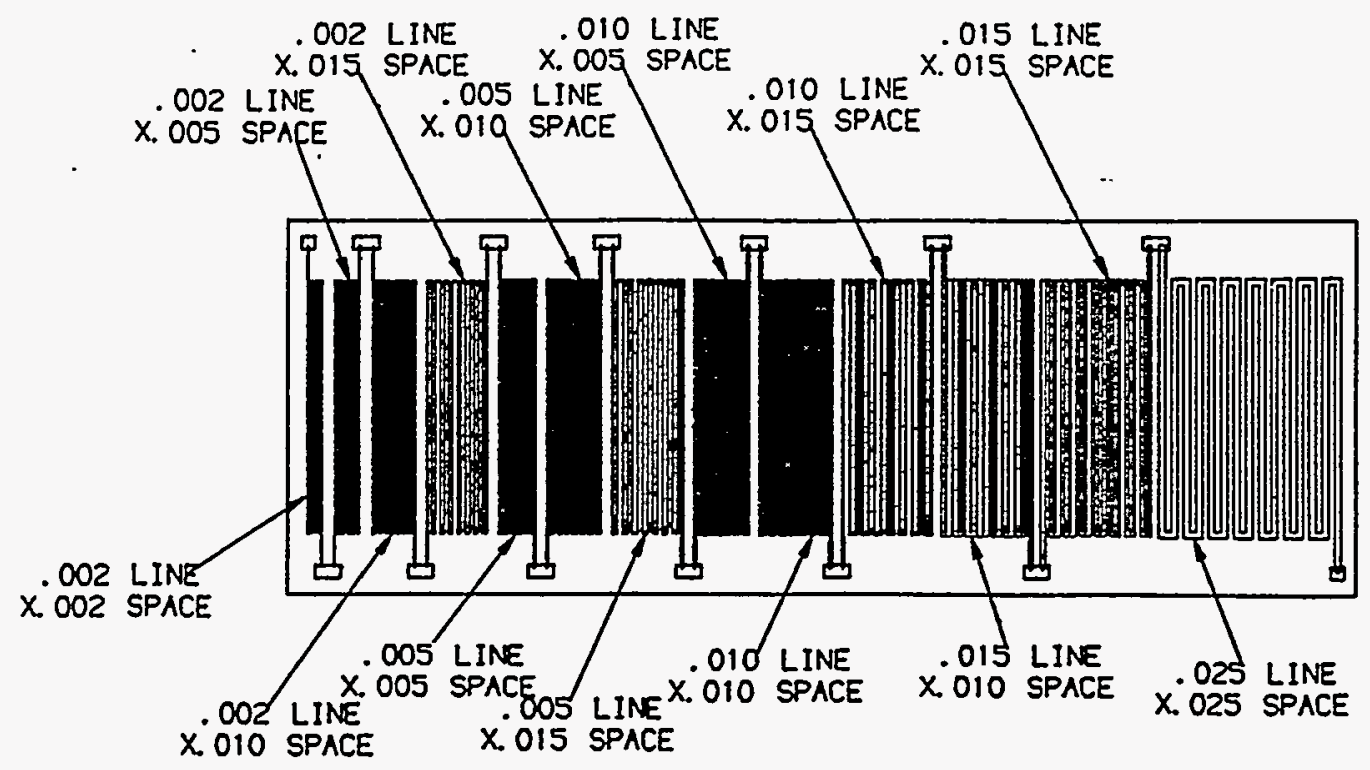

Figure 4. Capability Panel Line/Space Snake Pattern (Coupon C)

The advantage of the serpentine pattern is that the multiple line and space widths give an immediate visual indication of the artwork reproduction capability immediately after developing. The particular coupon used was $C_{1}$ located in the bottom half of the panel.

A visual qualitative analysis was done to verify the photoresist integrity after developing. The photoresist was shiny (as an example, a matte finish is an indication of improper cure due to low exposure energy or excessive developing temperature), the path widths were sharply defined, and some 2-mil paths were defined. Panels 01, 07, 09, and 11 visually looked better after develop, which showed that the lower exposure setting (step 9) resulted in the best 2-mil line and space patterns. The conclusion from this information was that the pattern was visually acceptable after developing.

The developed path widths were then magnified and microphotographed at 100X, 500X and $1000 \mathrm{X}$, using the scanning electron microscope (SEM), and are shown in Figures 5 through 12. The microphotographs by themselves show little difference in the magnified sidewall. Additional microphotographs were taken to show the final etched circuit which are later explained in this report.

Because plating and etching would impact the definition of the final pattern, the optimum parameters were selected following the plating and etching processes. The processing parameters providing the best results after plating and etching were lamination temperature of $110^{\circ} \mathrm{C}$, exposure energy setting of 110 (step 9), and developing speed of 2.5 .

The factorial designed experiment included two groups of panels processed through photoimaging with identical parameters and split after developing. One group of panels was copper/tin-lead plated and the second group of panels was gold plated. 


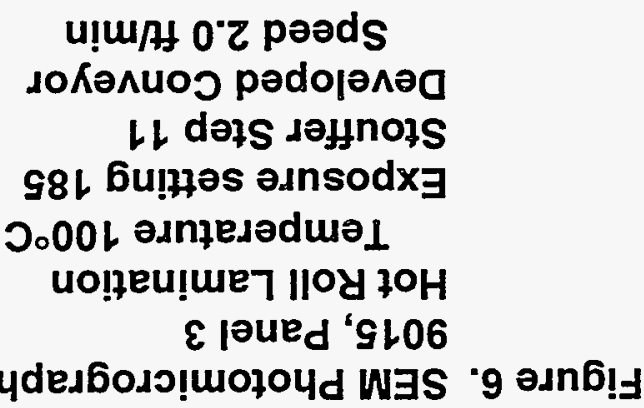
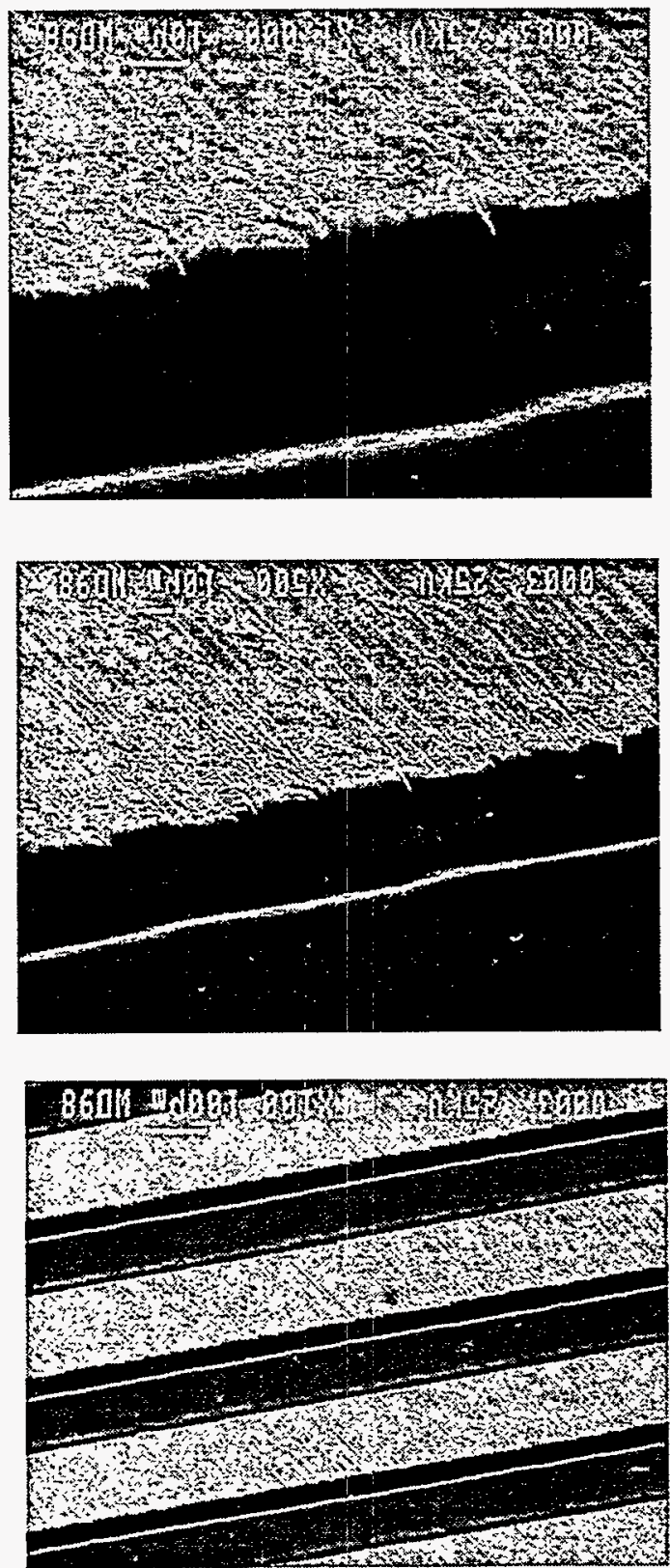

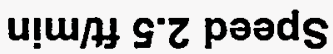 \\ גоКәлนоว pәdo|әлә \\ 6 dətS sәңnots

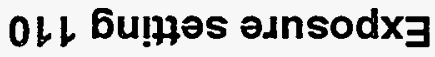

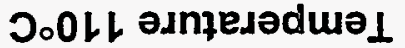 \\ uolfeu!ue 7 Iloy 70H \\ L pued 'SL06 to

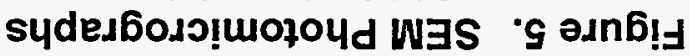
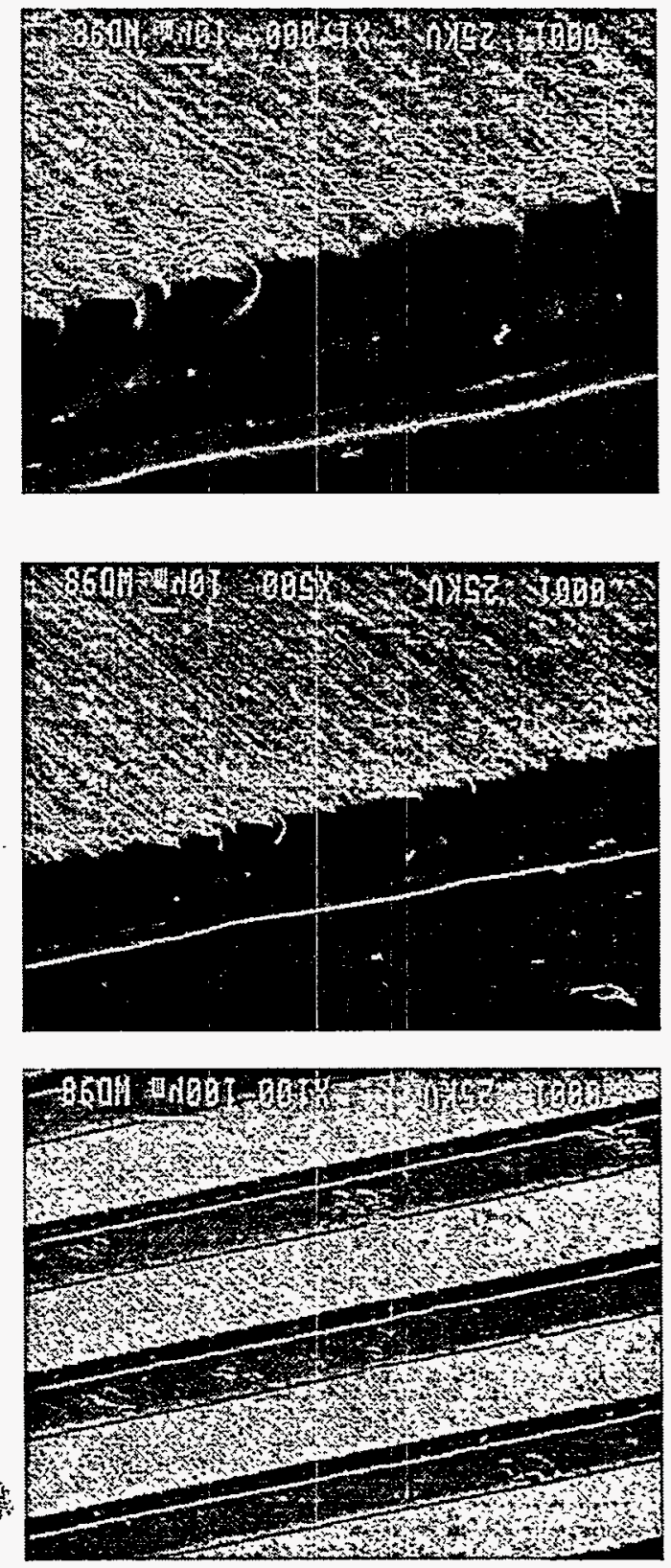

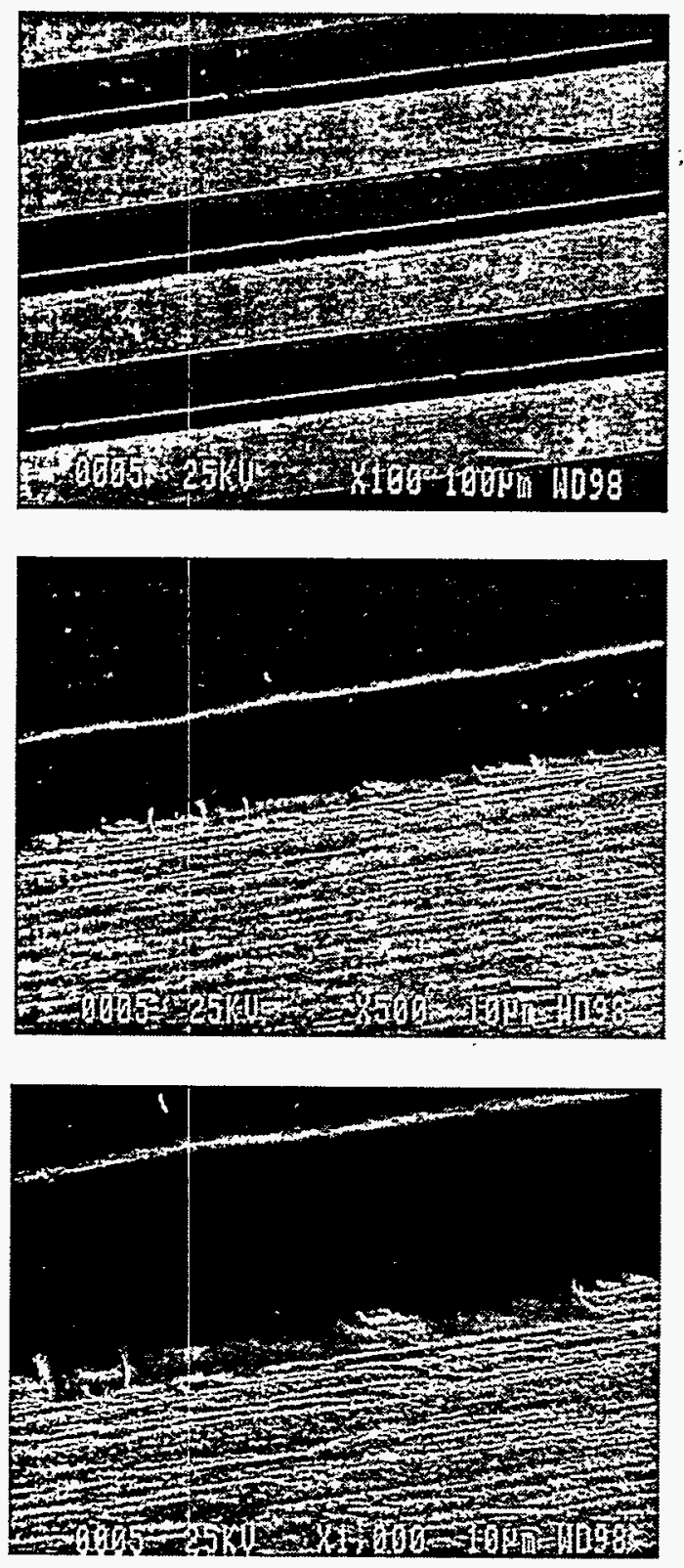

Figure 7. SEM Photomicrograph of DuPont Riston 9015, Panel 5 Hot Roll Lamination Temperature $110^{\circ} \mathrm{C}$ Exposure Setting 185 Stouffer Step 11 Developed Conveyor Speed $2.5 \mathrm{ft} / \mathrm{min}$
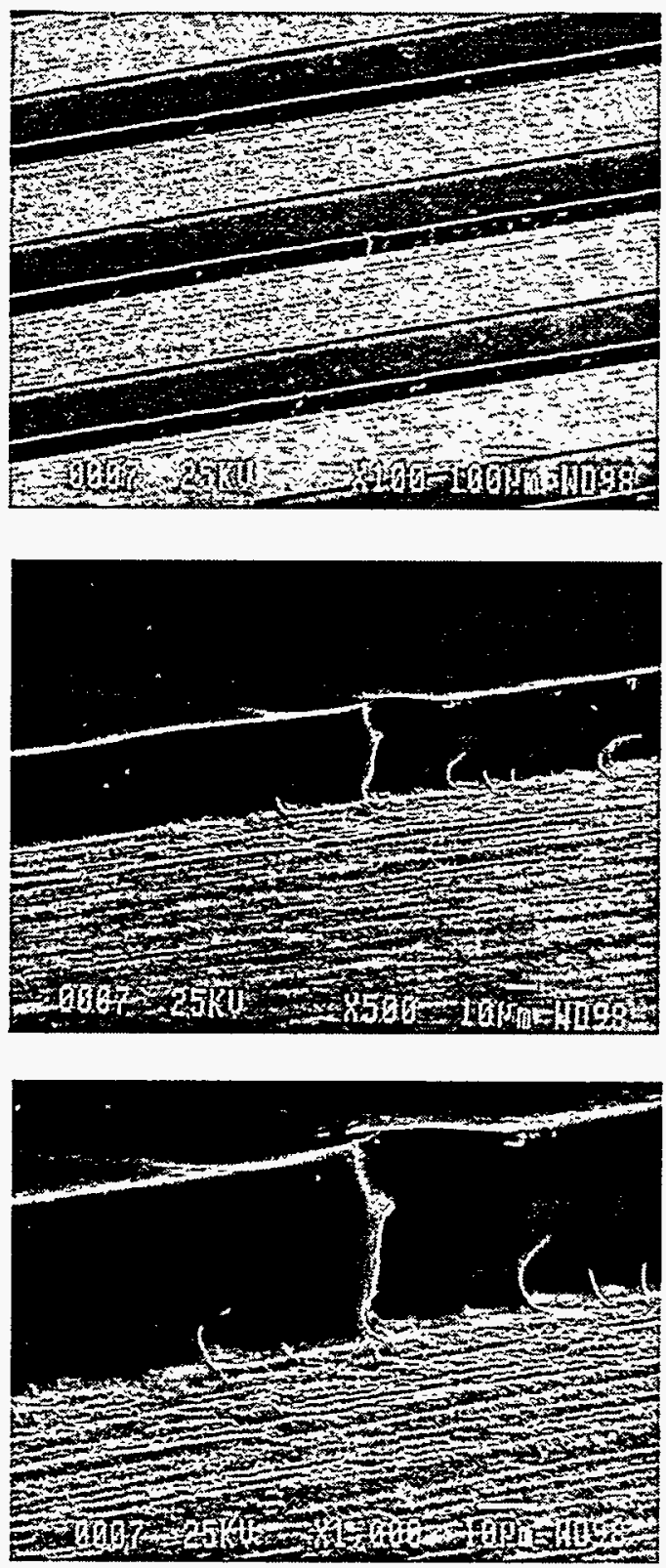

Figure 8. SEM Photomicrograph of DuPont Riston 9015, Panel 7 Hot Roll Lamination Temperature $100^{\circ} \mathrm{C}$ Exposure Setting 110 Stouffer Step 9 Developed Conveyor Speed $2.5 \mathrm{ft} / \mathrm{min}$ 

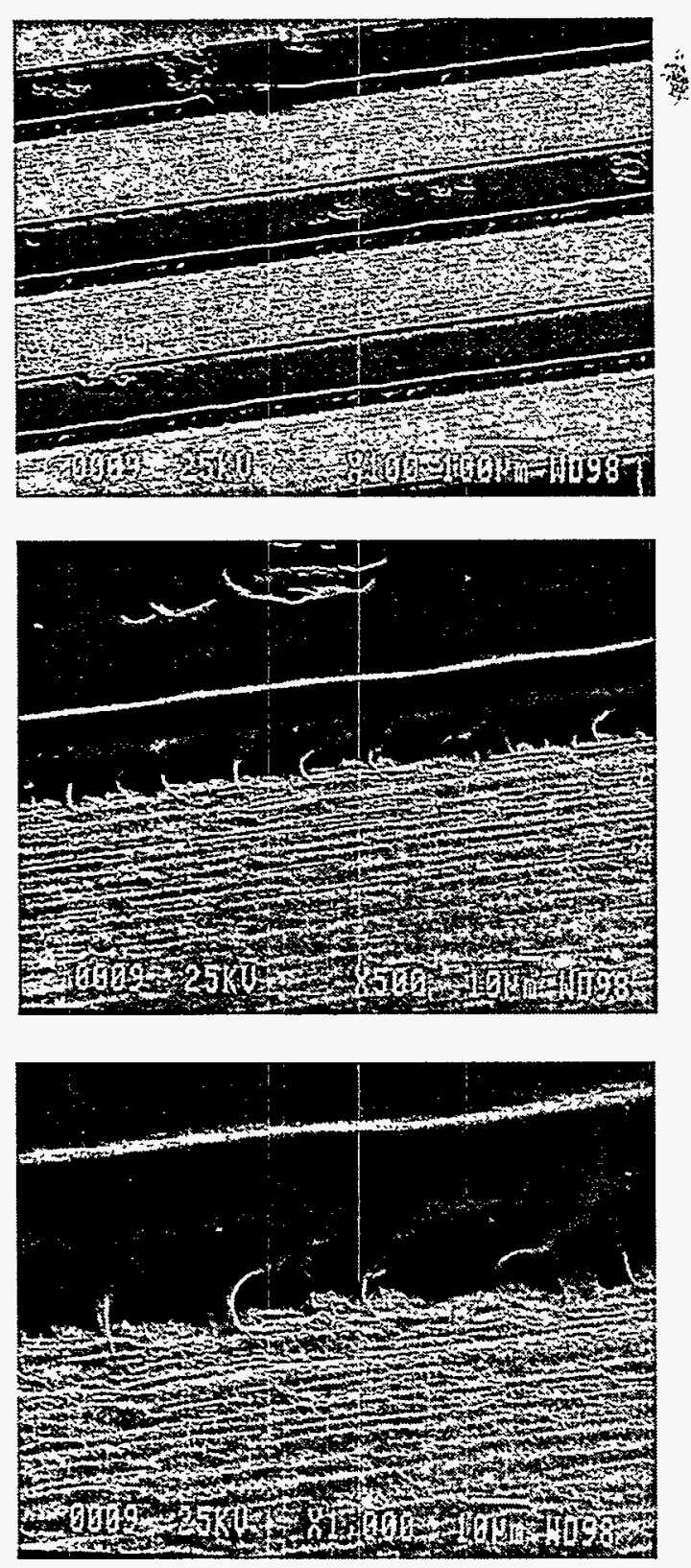

Figure 9. SEM Photomicrograph of DuPont Riston 9015, Panel 9 Hot Roll Lamination Temperature $110^{\circ} \mathrm{C}$ Exposure Setting 110 Stouffer Step 9 Developed Conveyor Speed $2.5 \mathrm{ft} / \mathrm{min}$
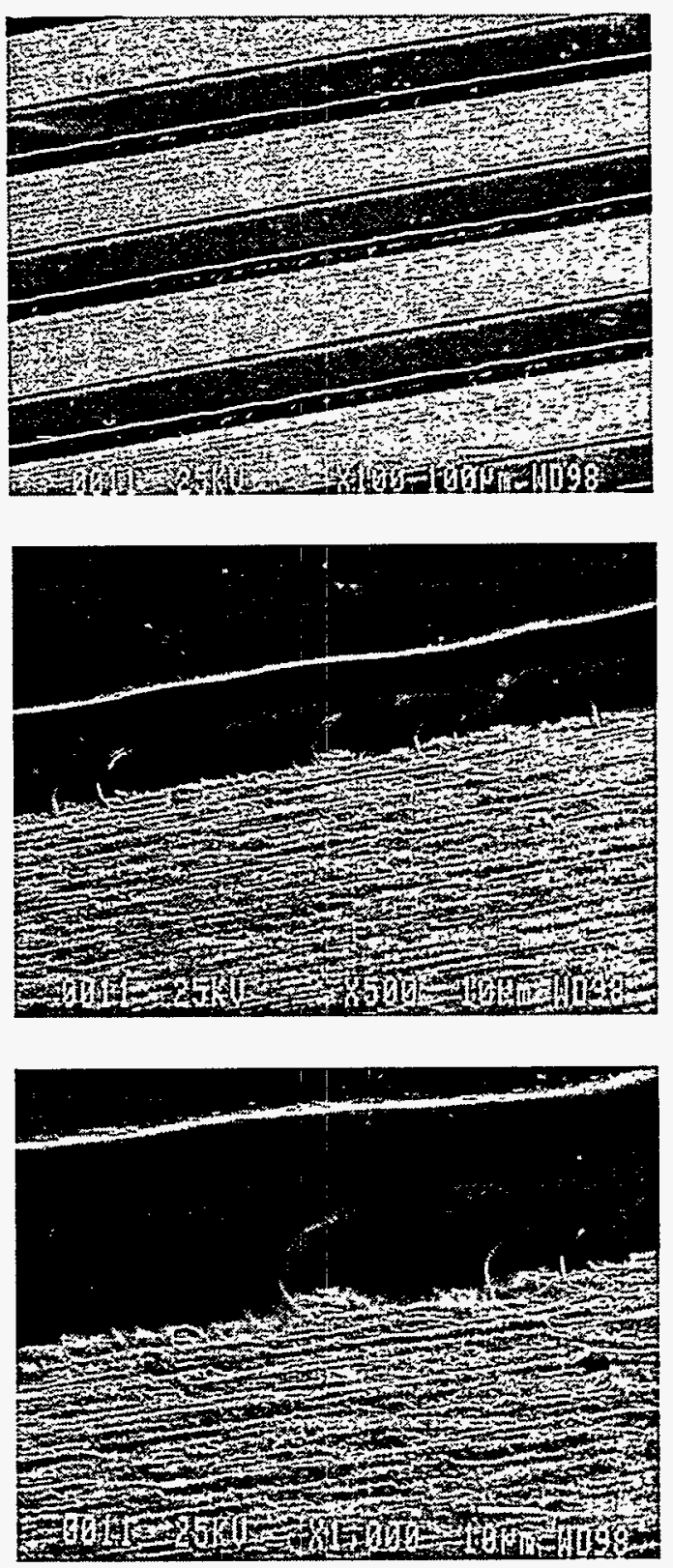

Figure 10. SEM Photomicrograph of DuPont Riston 9015, Panel 11 Hot Roll Lamination Temperature $100^{\circ} \mathrm{C}$ Exposure Setting 110 Stouffer Step 9 Developed Conveyor Speed $2.5 \mathrm{ft} / \mathrm{min}$ 

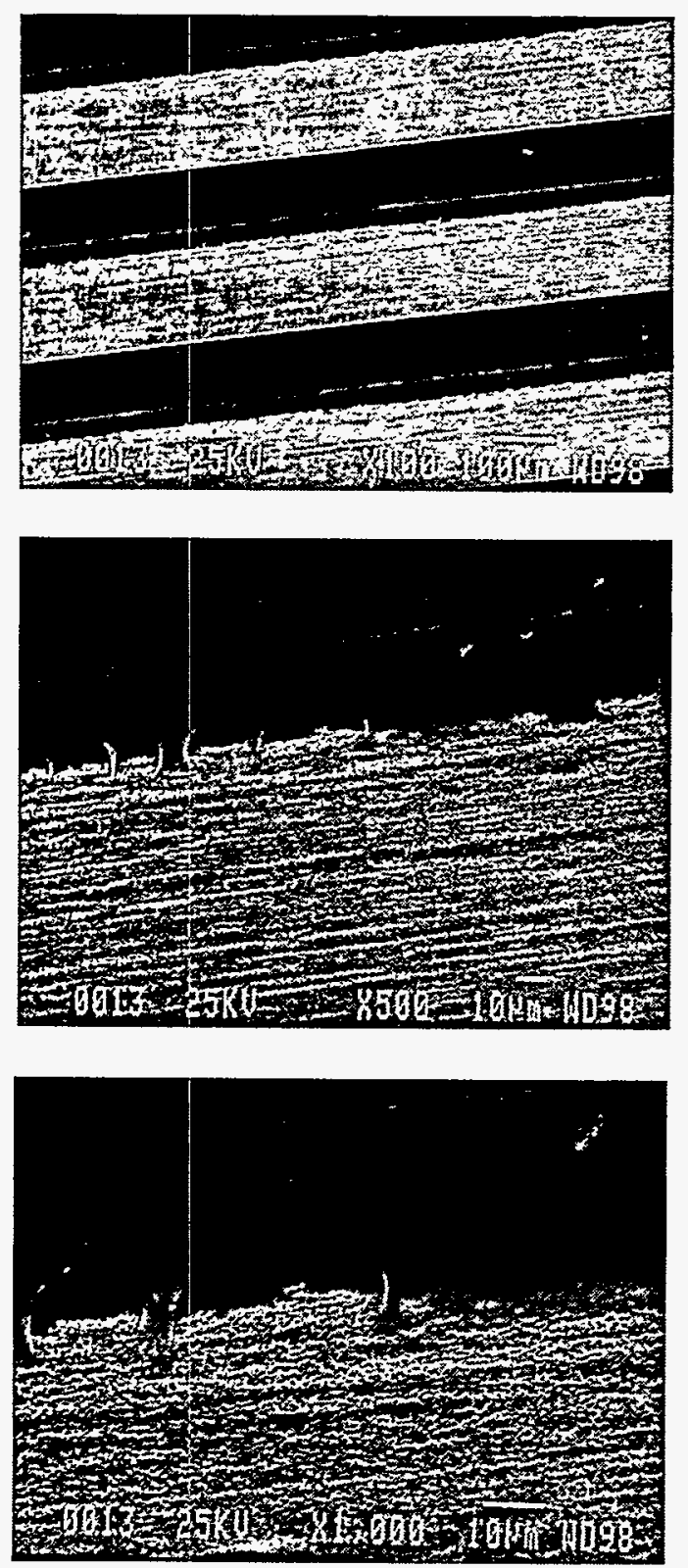

Figure 11. SEM Photomicrograph of DuPont Riston 9015, Panel 13 Hot Roll Lamination Temperature $100^{\circ} \mathrm{C}$ Exposure Setting 185 Stouffer Step 11 Developed Conveyor Speed $3.25 \mathrm{ft} / \mathrm{min}$
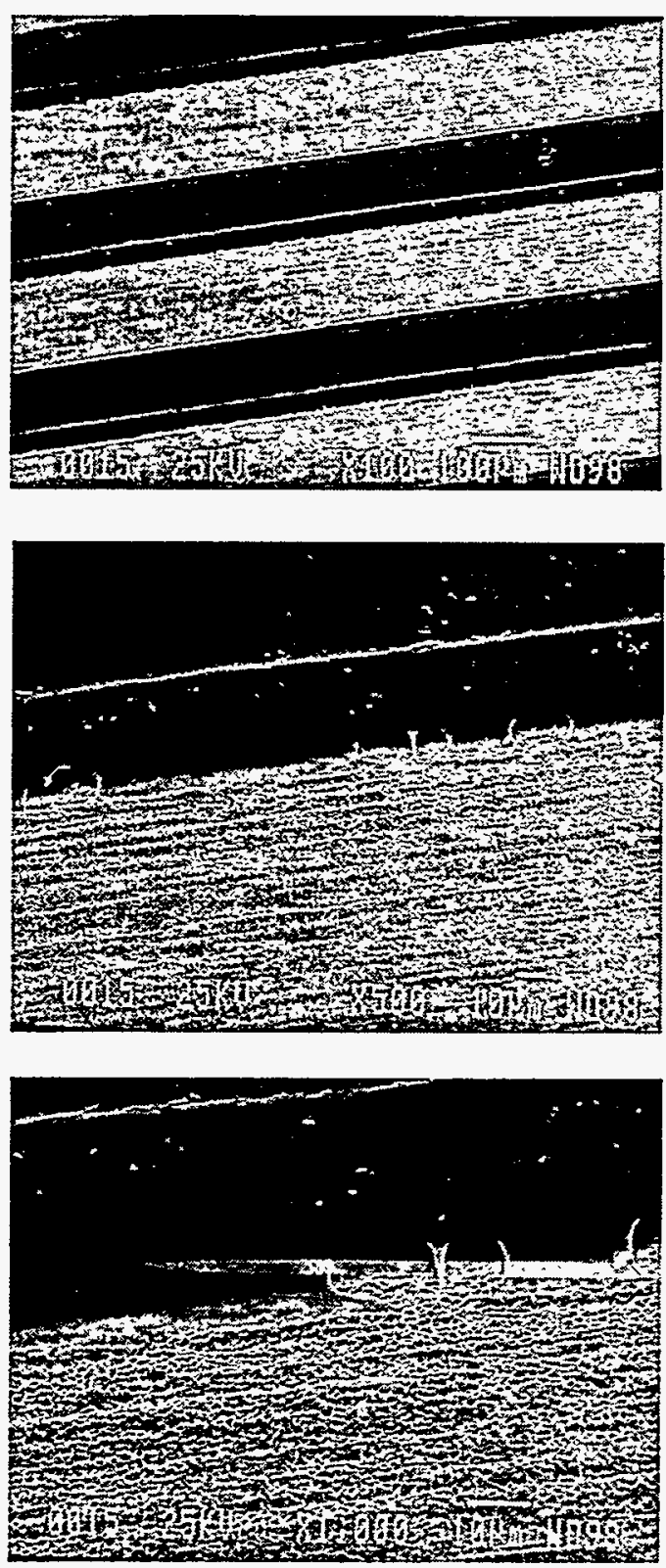

Figure 12. SEM Photomicrograph of DuPont Riston 9015, Panel 15 Hot Roll Lamination Temperature $110^{\circ} \mathrm{C}$ Exposure Setting 185 Stouffer Step 11 Developed Conveyor Speed $2.5 \mathrm{ft} / \mathrm{min}$ 


\section{Tin-Lead Plating}

The tin-lead portion of the DuPont 9015 evaluation consisted of 8 panels taken from the original 16 panels discussed in the Photoresist Image Performance evaluation. Table 6 lists specific panel numbers and processing conditions.

Table 6. Copper/Tin-Lead Panels and Processing Conditions

\begin{tabular}{||l|c|c|c|c|c|c|c|c||}
\hline Panel & 1 & 3 & 5 & 7 & 9 & 11 & 13 & 15 \\
\hline $\begin{array}{l}\text { Lamination } \\
\left({ }^{\circ} \mathrm{C}\right)\end{array}$ & 110 & 100 & 110 & 100 & 110 & 100 & 100 & 110 \\
\hline $\begin{array}{l}\text { Expose } \\
\text { (Setting/ } \\
\text { Step) }\end{array}$ & $\begin{array}{c}110 \\
9\end{array}$ & $\begin{array}{c}185 \\
11\end{array}$ & $\begin{array}{c}185 \\
11\end{array}$ & $\begin{array}{c}110 \\
9\end{array}$ & $\begin{array}{c}110 \\
9\end{array}$ & $\begin{array}{c}110 \\
9\end{array}$ & $\begin{array}{c}185 \\
11\end{array}$ & $\begin{array}{c}185 \\
11\end{array}$ \\
\hline $\begin{array}{l}\text { Develop } \\
\text { (Ft/Min) }\end{array}$ & 2.5 & 2.0 & 2.5 & 2.5 & 2.5 & 2.5 & 3.25 & 2.5 \\
\hline
\end{tabular}

The processing sequence using DuPont 9015 for copper/tin-lead plating on the KCD capability panel was:

1. Copper Pre-image Cleaning - Conveyorized Chemical Cleaning (Table 7)

2. Photoresist Lamination - Hot Roll Laminating of photoresist

3. Photoresist Exposure - Exposing of photoresist to Ultra-violet (UV) light

4. Photoresist Develop - Conveyorized Developing of photoresist

5. Acid Copper Electroplate - Emersion tank

6. Tin-Lead Electroplate - Emersion tank

7. Photoresist Strip - Conveyorized Stripping of photoresist

8. Copper Etch - Conveyorized Alkaline Etching of copper

9. Tin-lead Strip - Emersion tank

Table 7. Pre-Image Cleaning (Chemcut 547, CE \#55762)

\begin{tabular}{||l|l|l|l|l|l||}
\hline $\begin{array}{l}\text { Process } \\
\text { Sequence }\end{array}$ & $\begin{array}{l}\text { Material } \\
\text { Name }\end{array}$ & Conc & Temp & $\begin{array}{l}\text { Dwell } \\
\text { Time }\end{array}$ & $\begin{array}{l}\text { Belt } \\
\text { Speed }\end{array}$ \\
\hline $\begin{array}{l}\text { Alkaline } \\
\text { Clean }\end{array}$ & $\begin{array}{l}\text { MacDermid } \\
\text { Metex P-507 }\end{array}$ & $19 \mathrm{~g} / \mathrm{L}$ & $\begin{array}{l}140^{\circ} \mathrm{F} \\
(135-145)\end{array}$ & $42 \mathrm{Sec}$ & $42 \mathrm{lpm}$ \\
\hline $\begin{array}{l}\text { Water } \\
\text { Rinse }\end{array}$ & Di Water & & & & \\
\hline Micro-Etch & $\begin{array}{l}\text { Sodium } \\
\text { Persulfate }\end{array}$ & $\begin{array}{l}60-150 \\
\mathrm{~g} / \mathrm{L}\end{array}$ & Ambient & $30 \mathrm{Sec}$ & \\
\hline & $\begin{array}{l}\text { SULFURIC } \\
\text { ACID }\end{array}$ & $\begin{array}{l}10-15 \\
\mathrm{~m} / \mathrm{L}\end{array}$ & & & \\
\hline & & & & & \\
\hline Water Rinse & DiWater & & Ambient & $30 \mathrm{Sec}$ & \\
\hline Dry & Warm Air Dry & & & $30 \mathrm{Sec}$ & \\
\hline
\end{tabular}


Some combinations of processing variables resulted in patterns with insignificant differences. Panels were visually evaluated and ranked after tin-lead plating by three people. The visual ranking was based on resist adhesion, definition of the lines and spaces, overall appearance of the photoresist after tin-lead plating.

Ranking was similar by all individuals, for instance panels $01,07,09$, and 11 were exposed to a step 9 and looked much better than the panels $03,05,13$, and 15, which were exposed to a step 11 ( $a$ higher amount of exposure energy than step 9).

The following photographs, Figures 13 through 18, depict the tin-lead plated process as produced by the evaluation.

Figure 13 shows the overall panel front of the standard capability image used for the printed circuit board process characterization. This panel has two coupons removed, as they were used for the SEM microphotographs described earlier in the report.

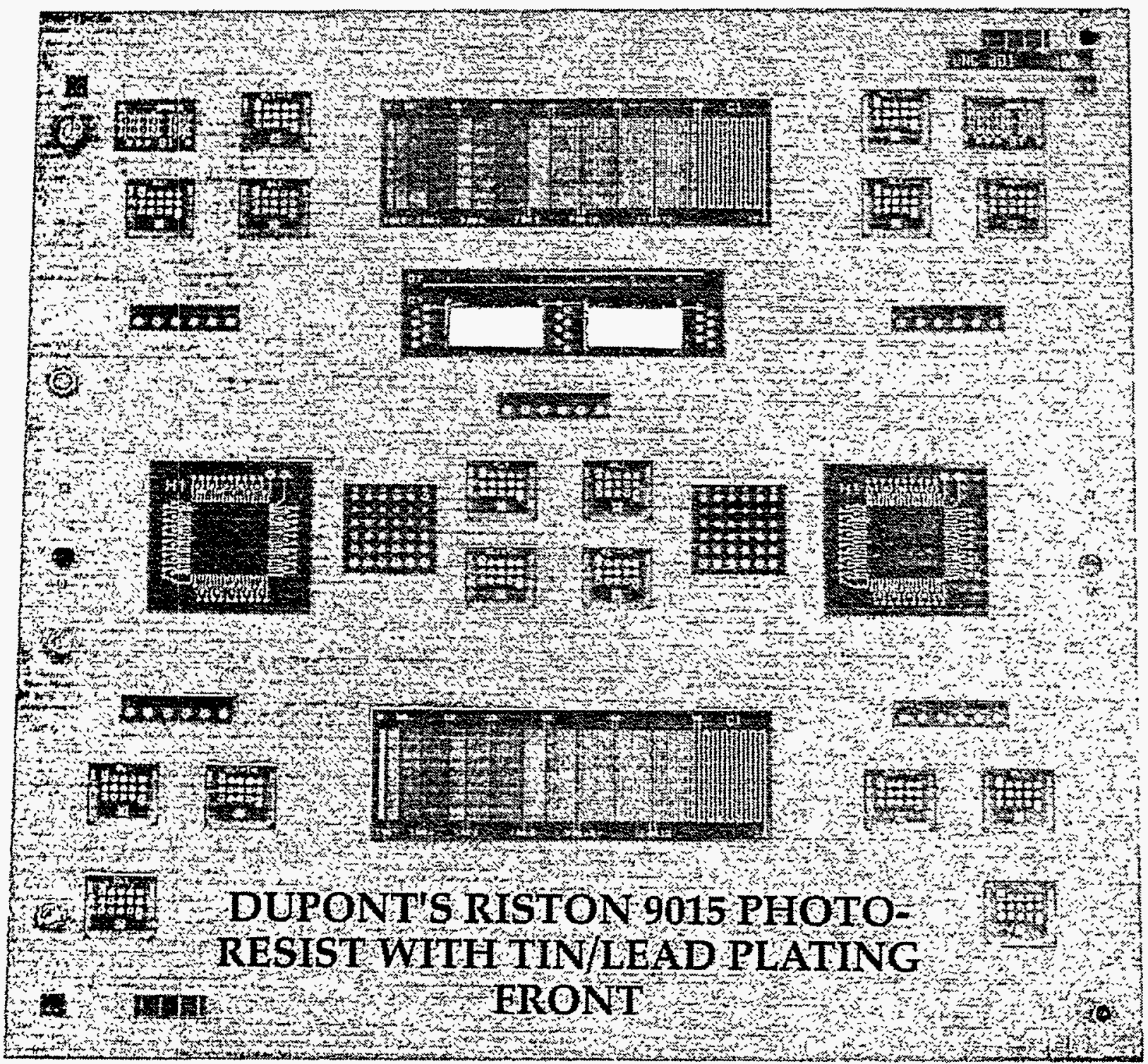

Figure 13. DuPont's Riston 9015 Photoresist with Gold Plating, Front View 
- Kuo uo!̣emuoju! jens!̣ dof pasn osje sem uodnoo s!

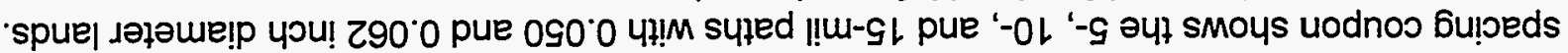

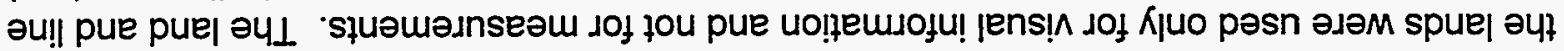
'pә|!!p łou sem jəued s!

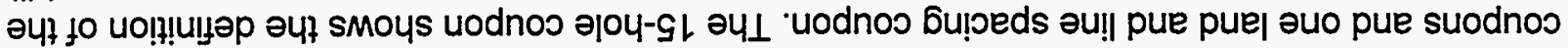

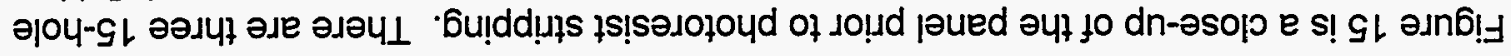

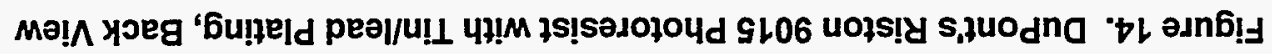

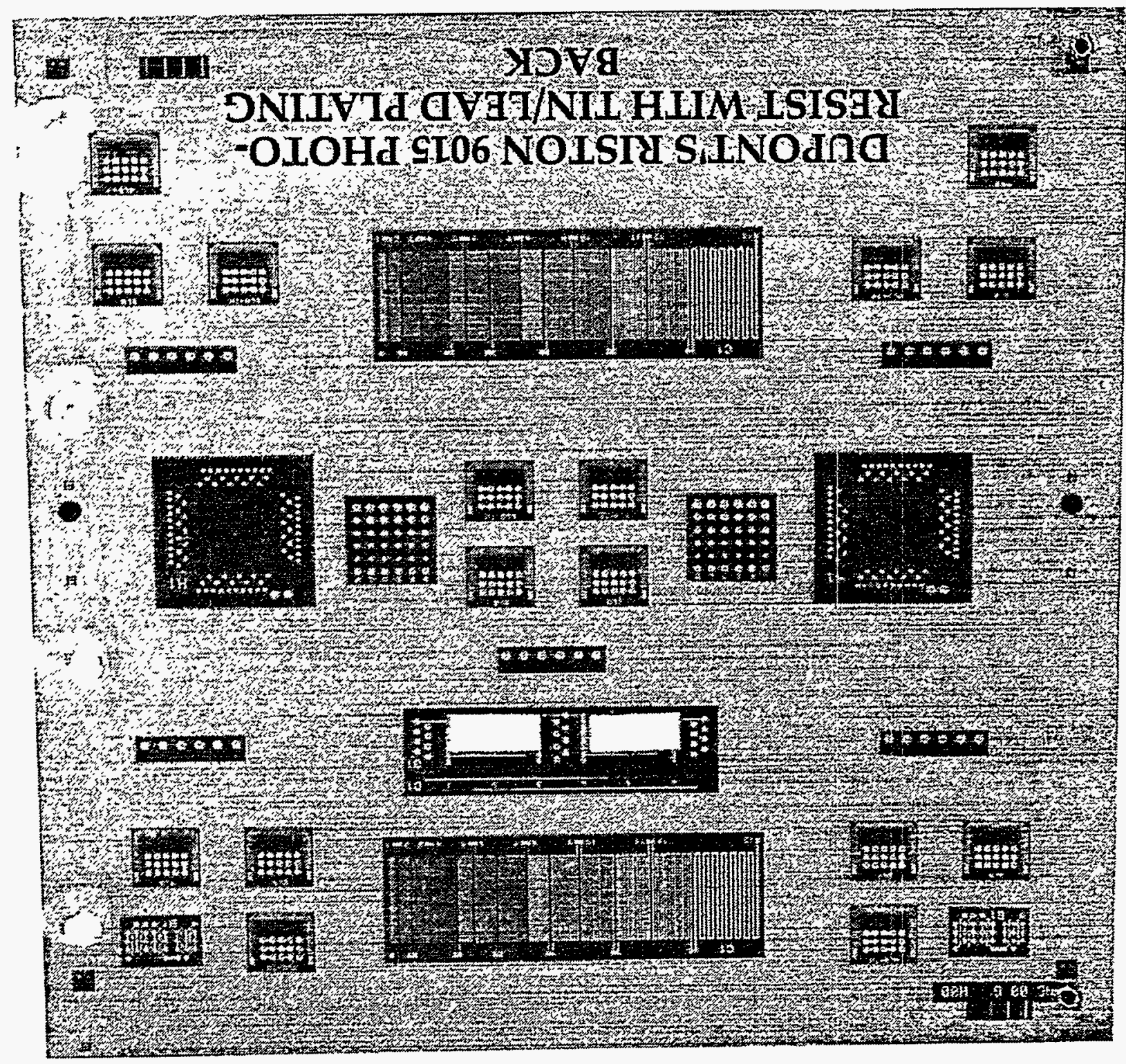

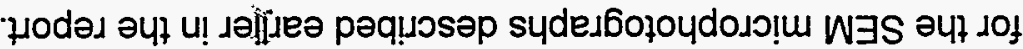

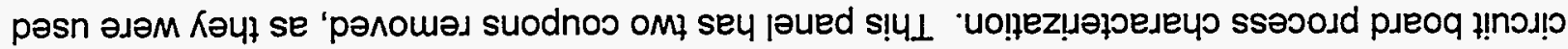

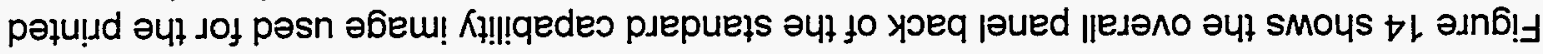




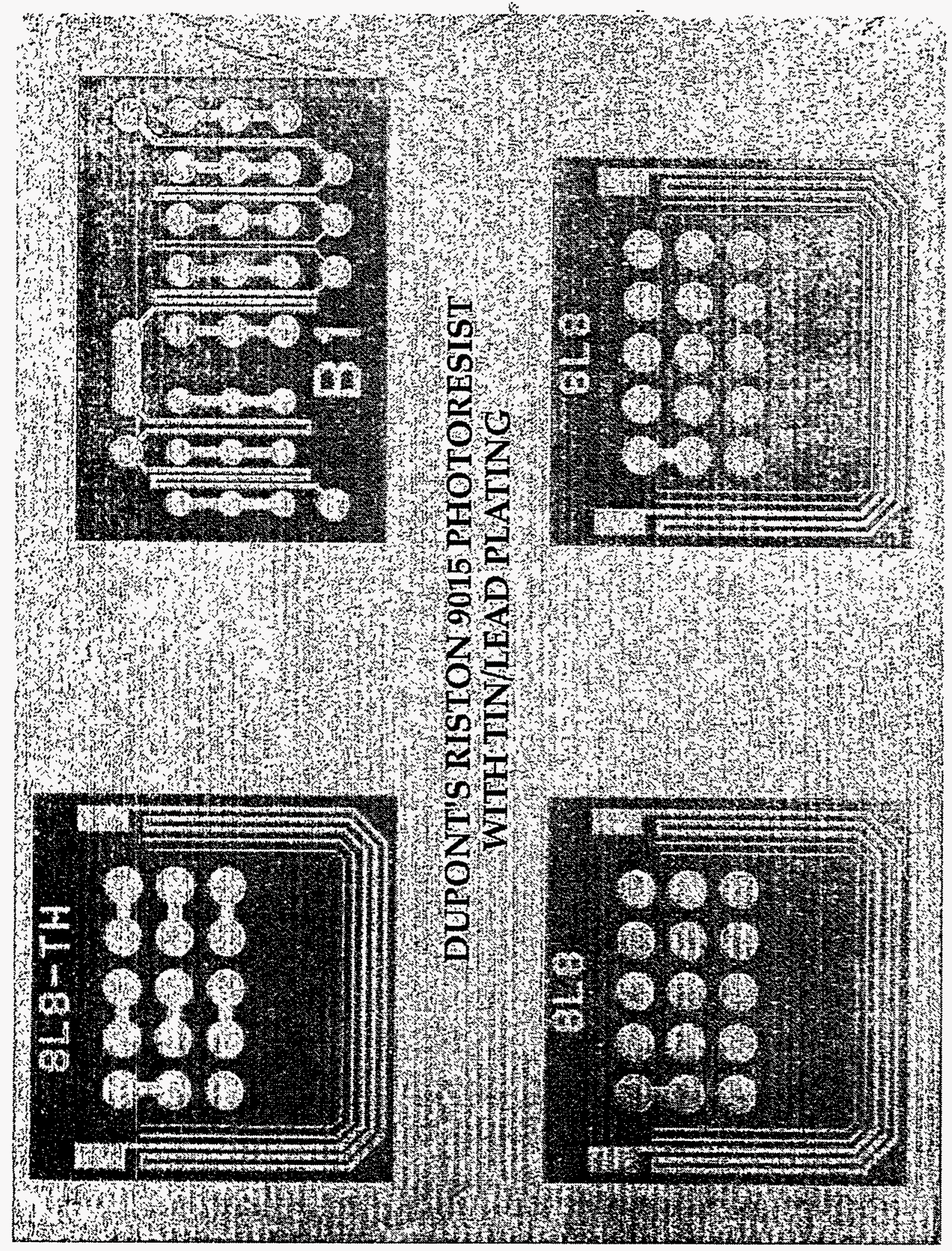

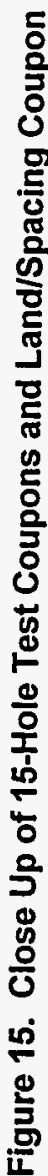


Figure 16 is the serpentine pattern showing the photoresist pattern broken up into 10 different line and spacing combinations. (See Table 5 for specific line widths.) The combination labeled 1 shows some developed line resolution, but the developing was incomplete as shown by no evidence of copper or tin-lead plating. The combination labeled 2 shows complete definition of copper and tin-lead plating, which is the 2-mil line with a 5-mil space.

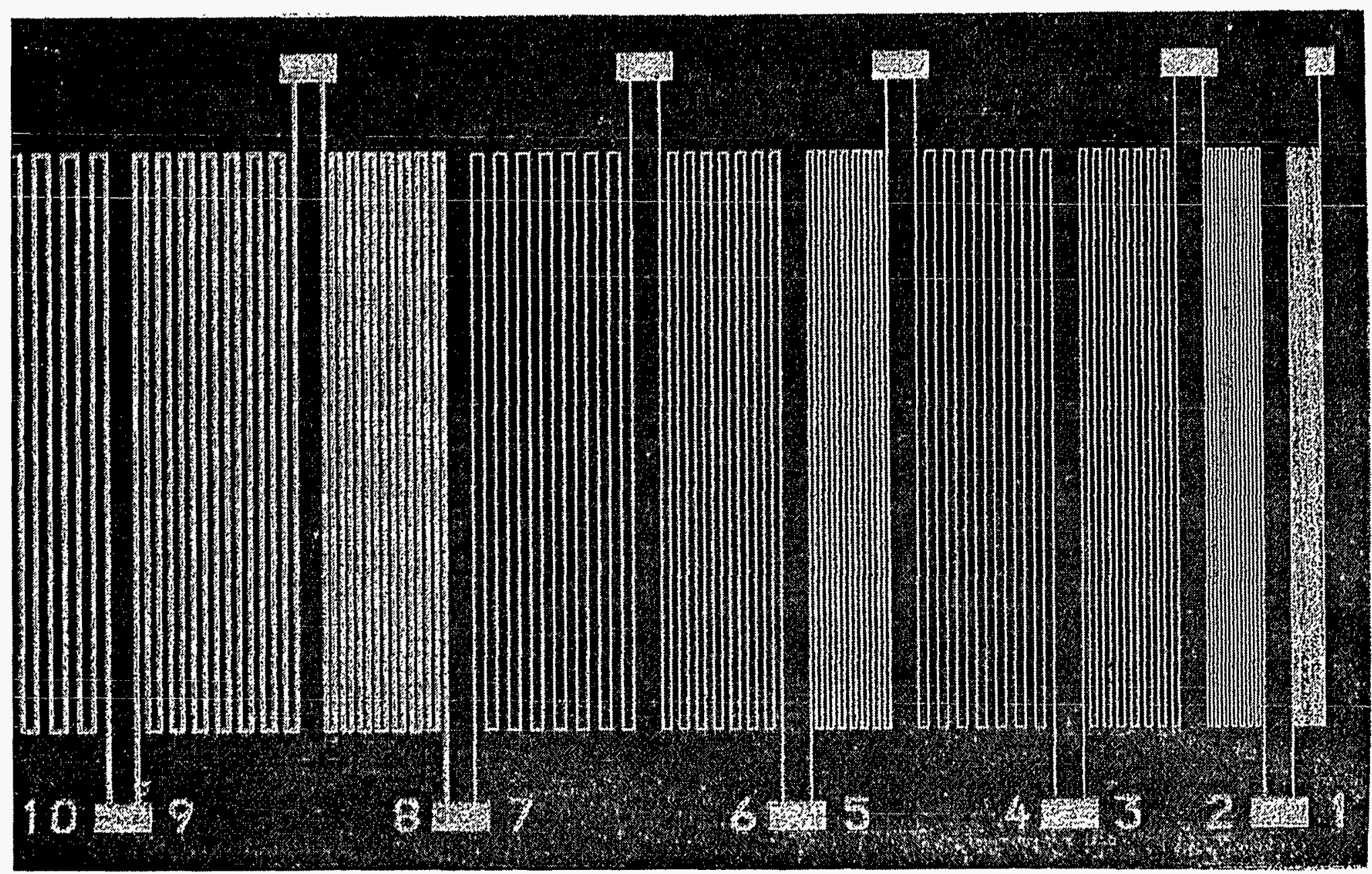

Figure 16. Close Up of Line/Space (Serpentine) Pattern 
Figure 17 shows the overall panel front with the standard capability image similar to Figures 13 and 14 , but with additional processing where the photoresist and the copper are chemically removed. Comparing this photo to Figure 13 shows' that some of the serpentine pattern was removed after etching. Figures 18 and 19 will show a close-up of the coupons and serpentine patterns to illustrate the line width after etching.

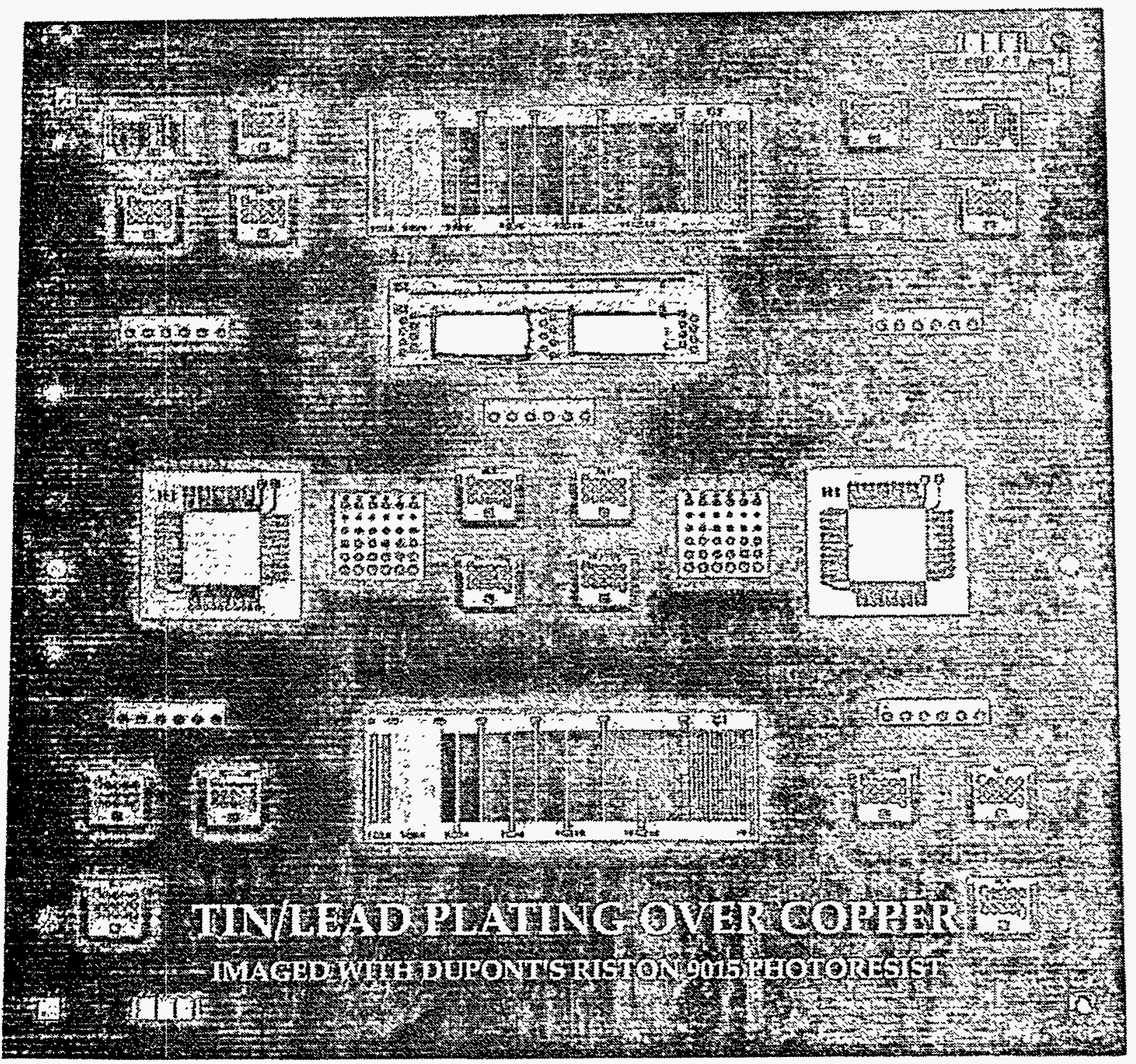

Figure 17. Overall Pattern After Etch

Figure 18 is a close-up of the etched coupons. There are three 15-hole coupons and one land/line spacing coupon in this picture. The 15-hole coupon shows the etched definition of the 5and 10-mil lines, but the 2-mil line was not maintained after etching. The land/line spacing coupon shows the etched 5-, 10-, and 15-mil lines. 


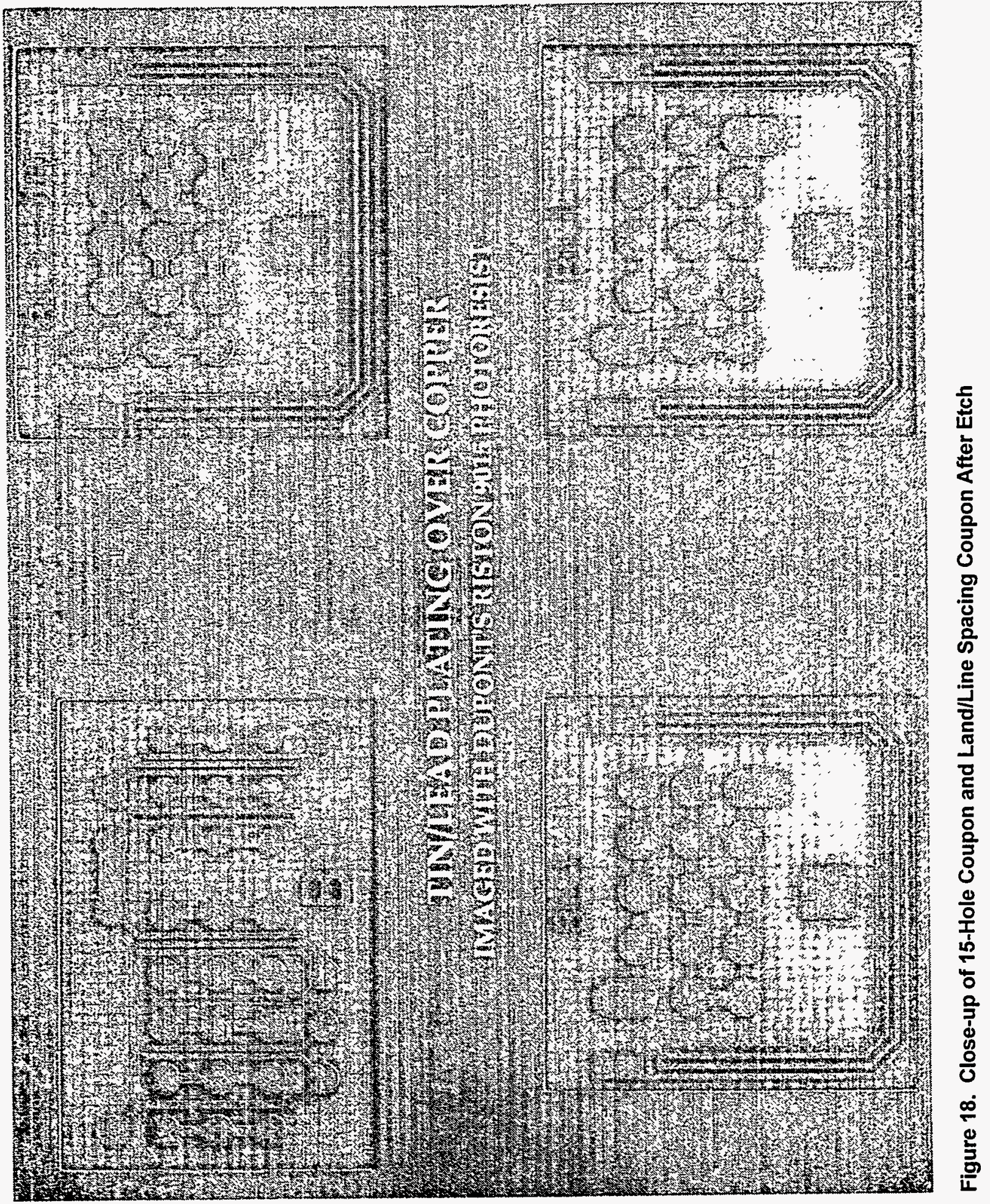




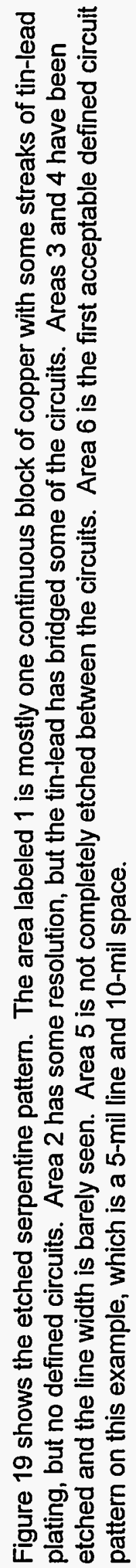

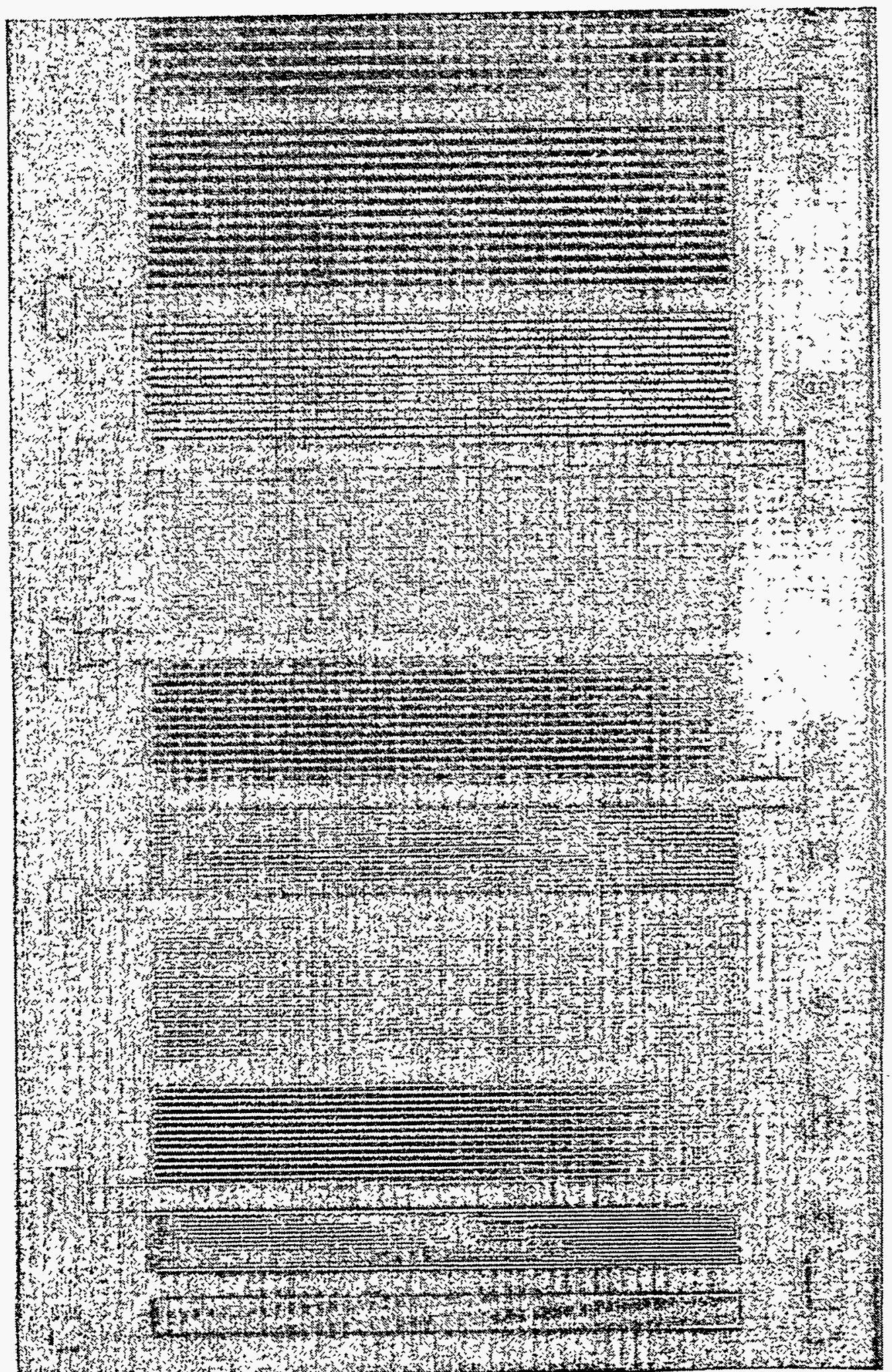

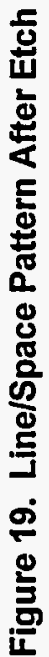


Figure 20 shows the tin-lead stripped off and is a SEM micrograph of the side wall.

\section{Gold Plating}

The gold plating portion of the DuPont 9015 evaluation consisted of 8 panels taken from the original 16 panels discussed earlier. Table 8 lists the specific panel numbers and the processing conditions.

Gold Plating Processing Sequence for the KCD Capability Panel using Dupont 9015

1. Copper pre-image cleaning conveyorized chemical cleaning (Table 7)

2. Photoresist lamination - hot roll laminating of photoresist

3. Photoresist exposure - exposing of photoresist to UV light

4. Photoresist develop - conveyorized developing of photoresist

5. Nickel electroplate - emersion tank

6. Gold electroplate - emersion tank

Some combinations of processing variables resulted in patterns with insignificant differences. Panels were visually evaluated and ranked after gold plating by three people. The visual ranking was based on resist adhesion, definition of the lines and spaces, and overall appearance of the photoresist after gold plating.

Ranking split the panels in two groups: 02 , $08,10,12$ and $04,06,14$, and 16. Panels $02,08,10$, and 12 were exposed to a stouffer step guide 9 , while panels 04,06 , 14 , and 16 were exposed to a stouffer step guide 11 (exposure energy increases in proportion to the exposure step reading).
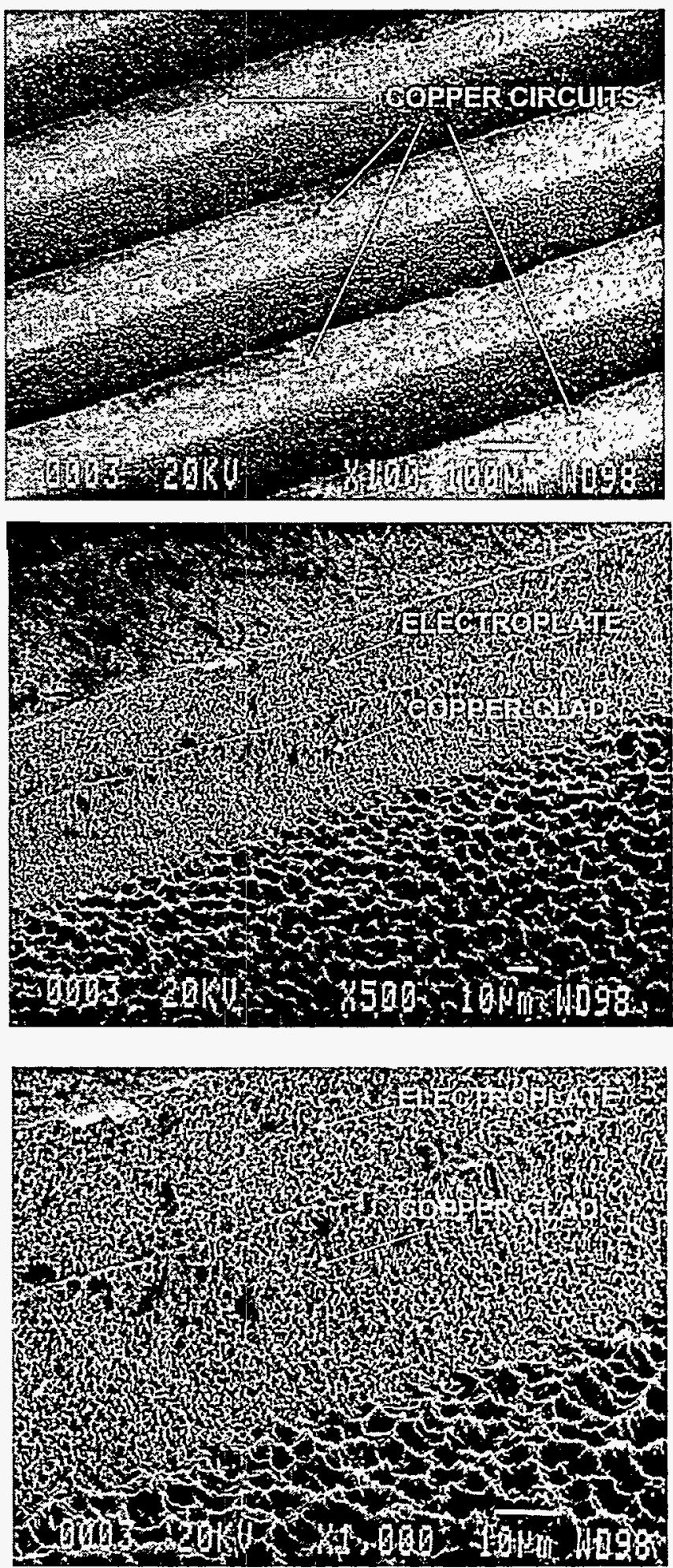

Figure 20. SEM Photomicrograph of Copper Circuit Sidewall, With the Tin-Lead Stripped After Etch 
Table 8. Specific Panel Numbers and Processing Conditions for Gold

\begin{tabular}{|l|c|c|c|c|c|c|c|c|}
\hline \hline Panel & 2 & 4 & 6 & 8 & 10 & 12 & 14 & 16 \\
\hline Lamination $\left({ }^{\circ} \mathrm{C}\right)$ & 110 & 100 & 110 & 100 & 110 & 100 & 100 & 110 \\
\hline Expose & 110 & 185 & 185 & 110 & 110 & 110 & 185 & 185 \\
(Setting/Step) & 9 & 11 & 11 & 9 & 9 & 9 & 11 & 11 \\
\hline Develop (ft/min) & 2.5 & 2.0 & 2.5 & 2.5 & 2.5 & 2.5 & 3.25 & 2.5 \\
\hline
\end{tabular}

Table 9. Nickel Sulfamate Electroplate (Barrett Sn, Tank BB-30)

\begin{tabular}{||l|l|l|l||}
\hline Parameter & $\begin{array}{l}\text { Actual } \\
(03-94)\end{array}$ & $\begin{array}{l}\text { Lower } \\
\text { Limit }\end{array}$ & $\begin{array}{l}\text { Upper } \\
\text { Limit }\end{array}$ \\
\hline Nickel (g/L) & 84 & 70 & 90 \\
\hline Boric Acid (g/L) & 33.7 & 0 & 3 \\
\hline $\mathrm{pH}$ & 4.4 & 305 & 4.5 \\
\hline Temp. ( $\left.{ }^{\circ} \mathrm{F}\right)$ & 130 & 120 & 140 \\
\hline Plating Amps (ASF) & 20 & 20 & 50 \\
\hline
\end{tabular}

Nickel Plating Calculation:

Ampere-minutes

per panel $=$ (Area sq in $) \times(9314$ plating

factor) $\times$ (thickness desired)

Thickness $=0.0001$ inch minimum

Ampere minutes per panel $=$ target 0.0005

inch

Area $=226 \mathrm{sq}$ in

Table 10. High-Purity Gold Bath (Soft Gold, PY-AU-Bond (DD-30)

\begin{tabular}{||l|l|l|l|l||}
\hline Parameter & $\begin{array}{l}\text { Actual } \\
(3-15-94)\end{array}$ & $\begin{array}{l}\text { Target } \\
\text { Values }\end{array}$ & $\begin{array}{l}\text { Lower } \\
\text { Limit }\end{array}$ & $\begin{array}{l}\text { Upper } \\
\text { Limit }\end{array}$ \\
\hline $\mathrm{pH}$ & 6.77 & 6.8 & 6.0 & 7.5 \\
\hline Baume & 17.8 & 20 & 15.0 & 25.0 \\
\hline $\begin{array}{l}\text { Gold } \\
\text { Concentration } \\
(\mathrm{g} / \mathrm{L})\end{array}$ & 9.6 & 10.2 & 4.1 & 16.4 \\
\hline
\end{tabular}

Gold plating calculation:

Ampere-minutes

per panel $=($ Area sq in $) \times$ (2840 plating

factor) $\times$ (thickness desired)

Thickness $=0.0001$ inch minimum

Ampere minutes per panel $=$ target 0.0003

inch

Amps per panel $=1$ ASF

thickness of gold is 0.0002 min generally

$0.0002 / 0.0003$

The SEM Micrograph shows the final circuit of panel 10. This panel shows some undercutting, caused by extended etching time.

Figures 21 and 22 show the overall front and back views of panel 10 with the standard capability image used for the printed circuit board process characterization. This panel was gold plated, but has not been stripped of the photoresist.

Figure 23 is a close-up of the coupons on the panel prior to photoresist stripping: there are three 15-hole coupons and one land and line spacing coupon. The 15-hole coupon shows the definition of the 2-, 5-, and 10-mil lines. The land and line spacing coupon shows the 5-, 10-, and 15-mil lines showing definition. 


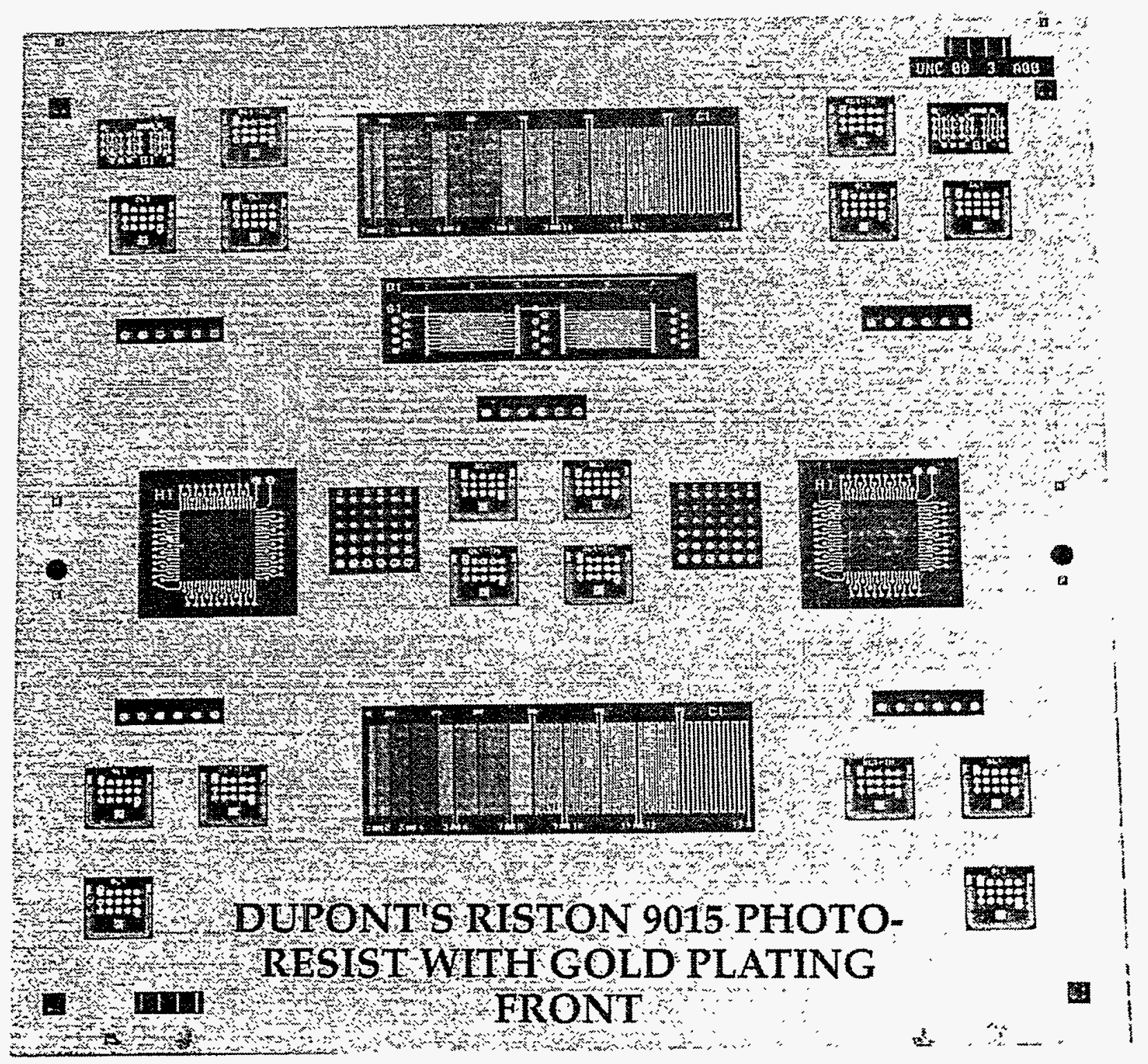

Figure 21. DuPont's Riston 9015 Photoresist with Gold Plating, Front View

Figure 24 shows the serpentine pattern broken up into 1 through 10 different line and spacing combinations (Table 5 ). The lines in the area labeled 1 are not completely defined. The lines were not completely defined at develop, and are gold plated as one large block. The combination labeled 2 has complete definition with a 2-mil line and a 5-mil space. (See Table 5 for specific line widths.) 


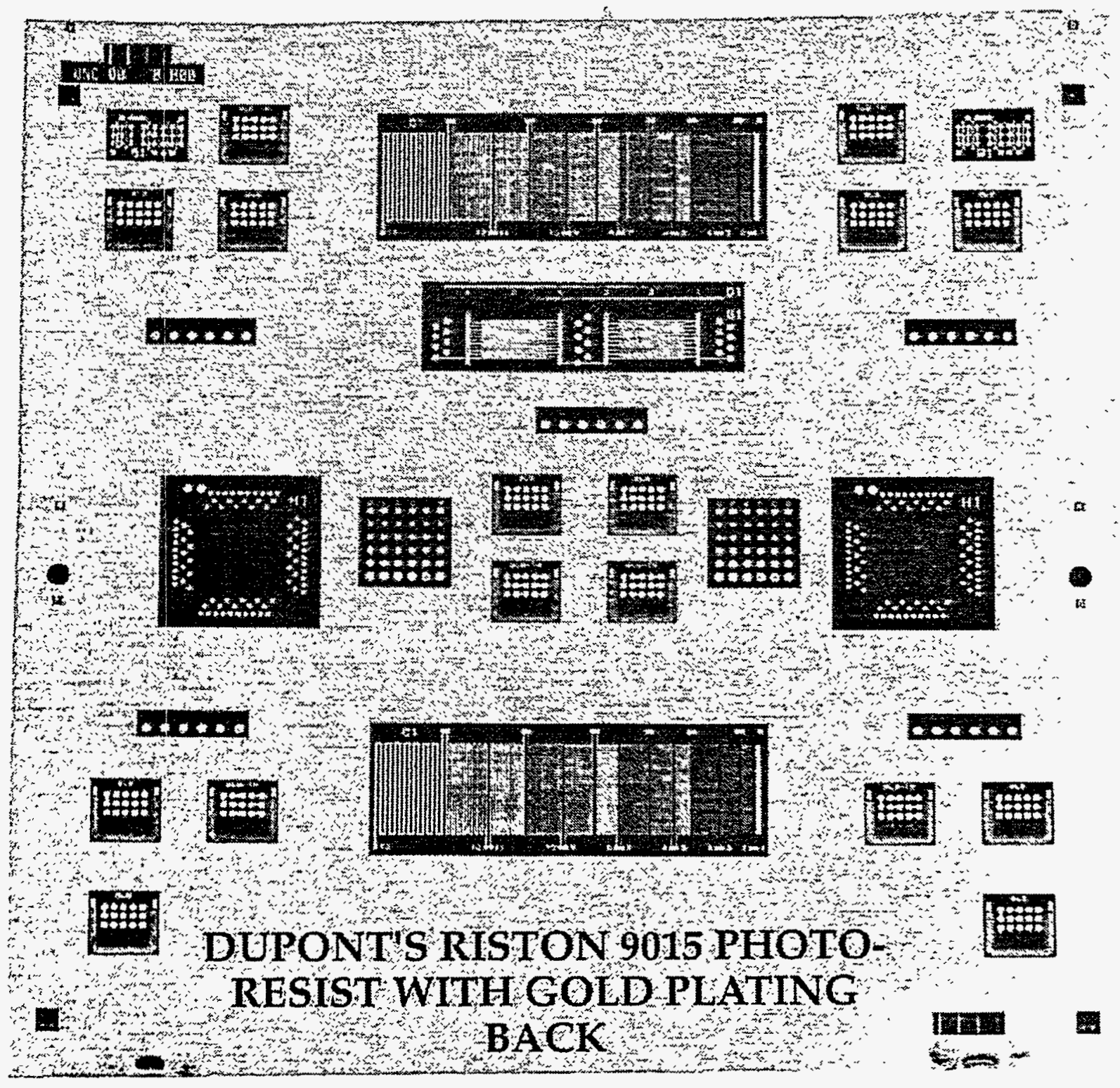

Figure 22. DuPont's Riston 9015 Photoresist with Gold Plating, Back View 

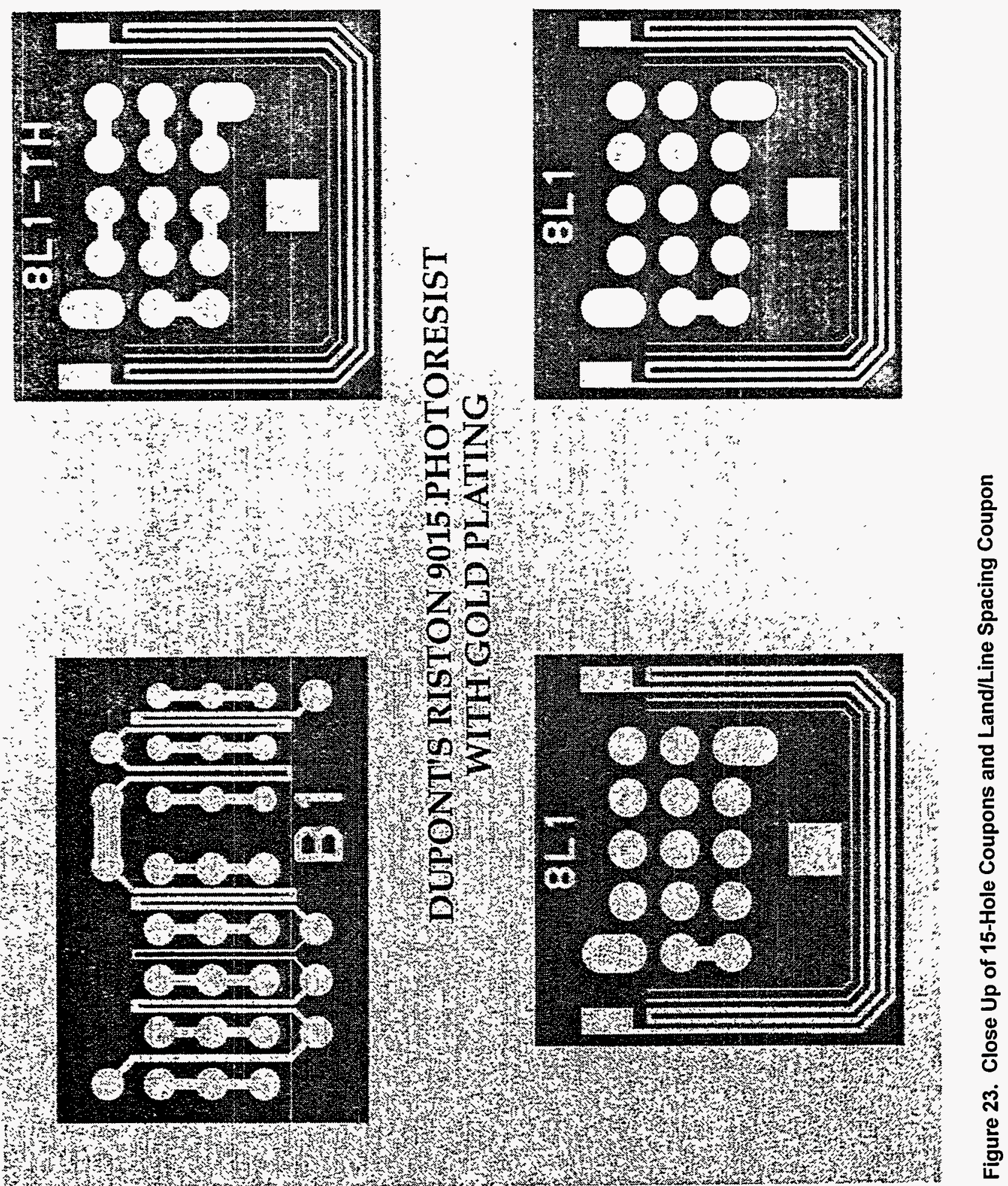


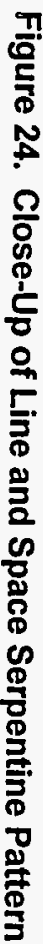

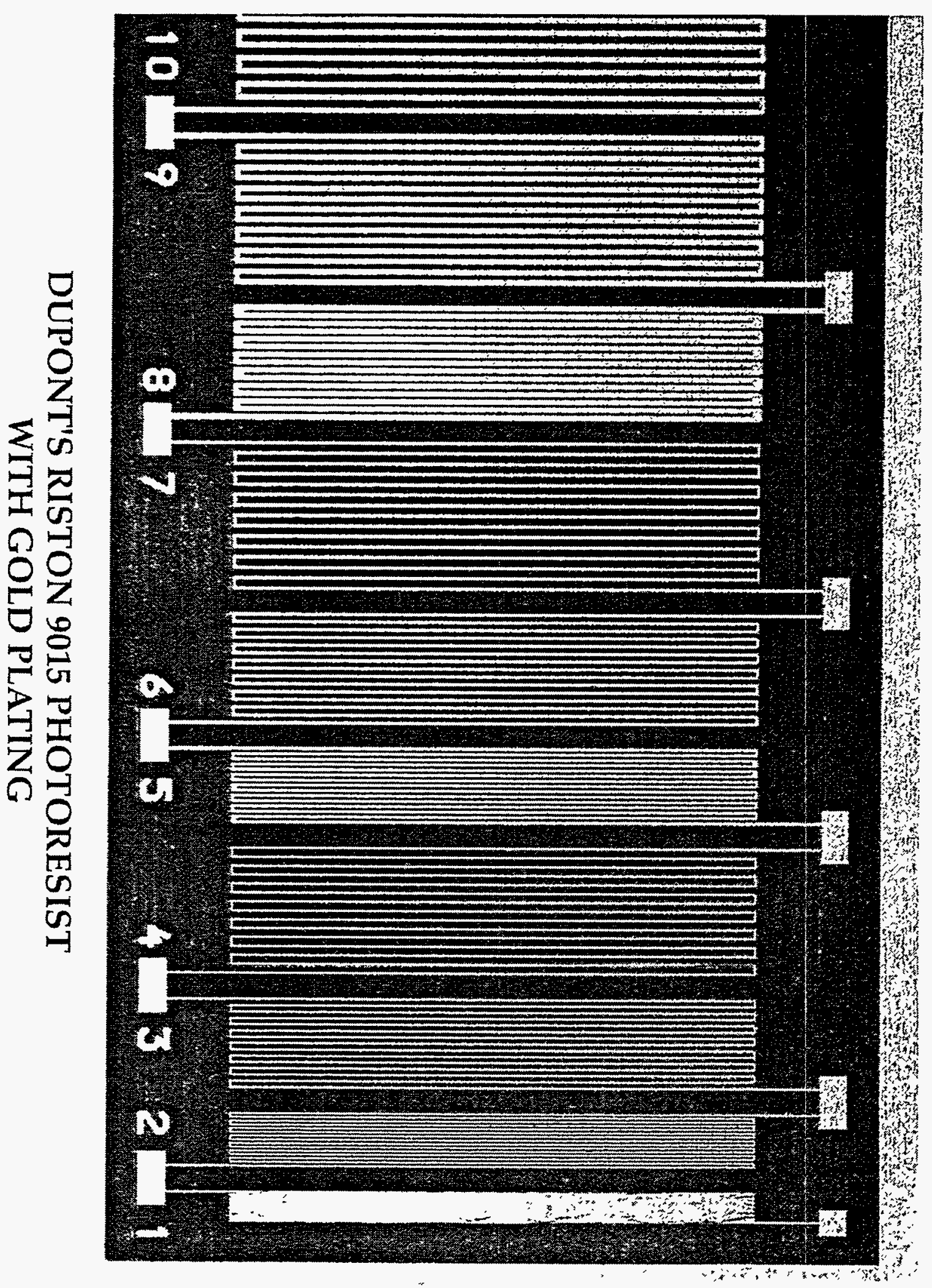




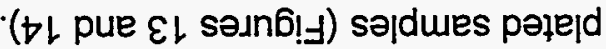

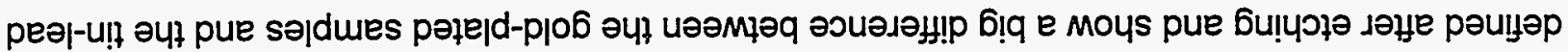

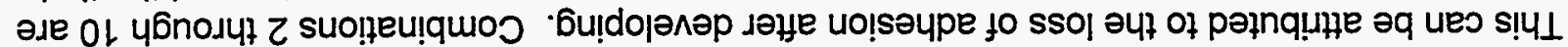

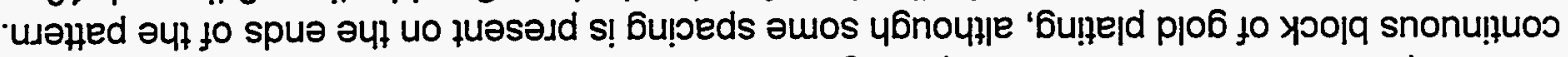

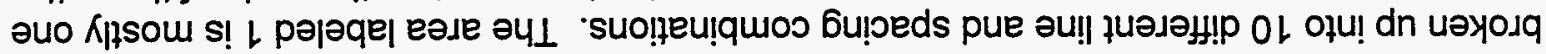

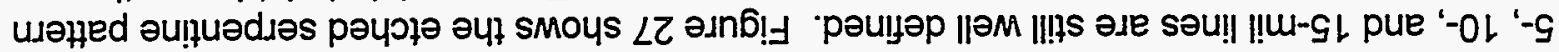

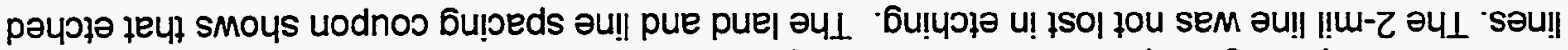

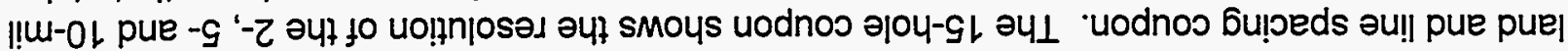

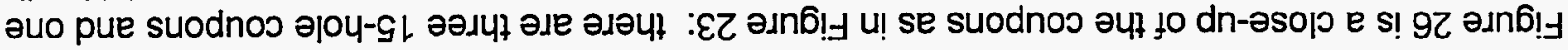

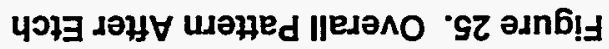

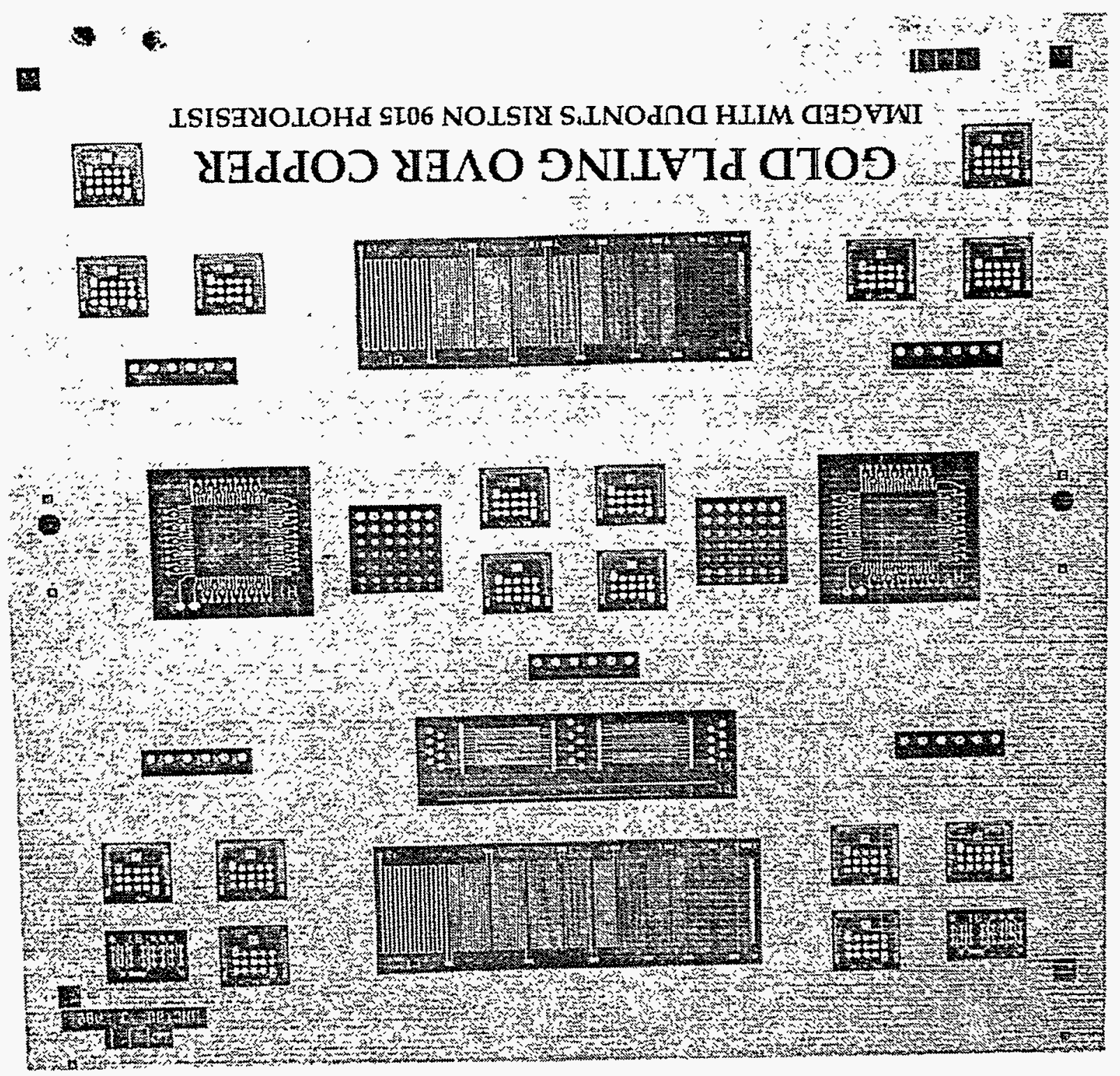

菑

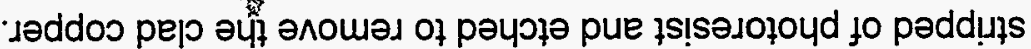

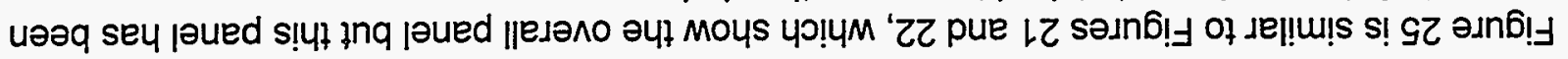




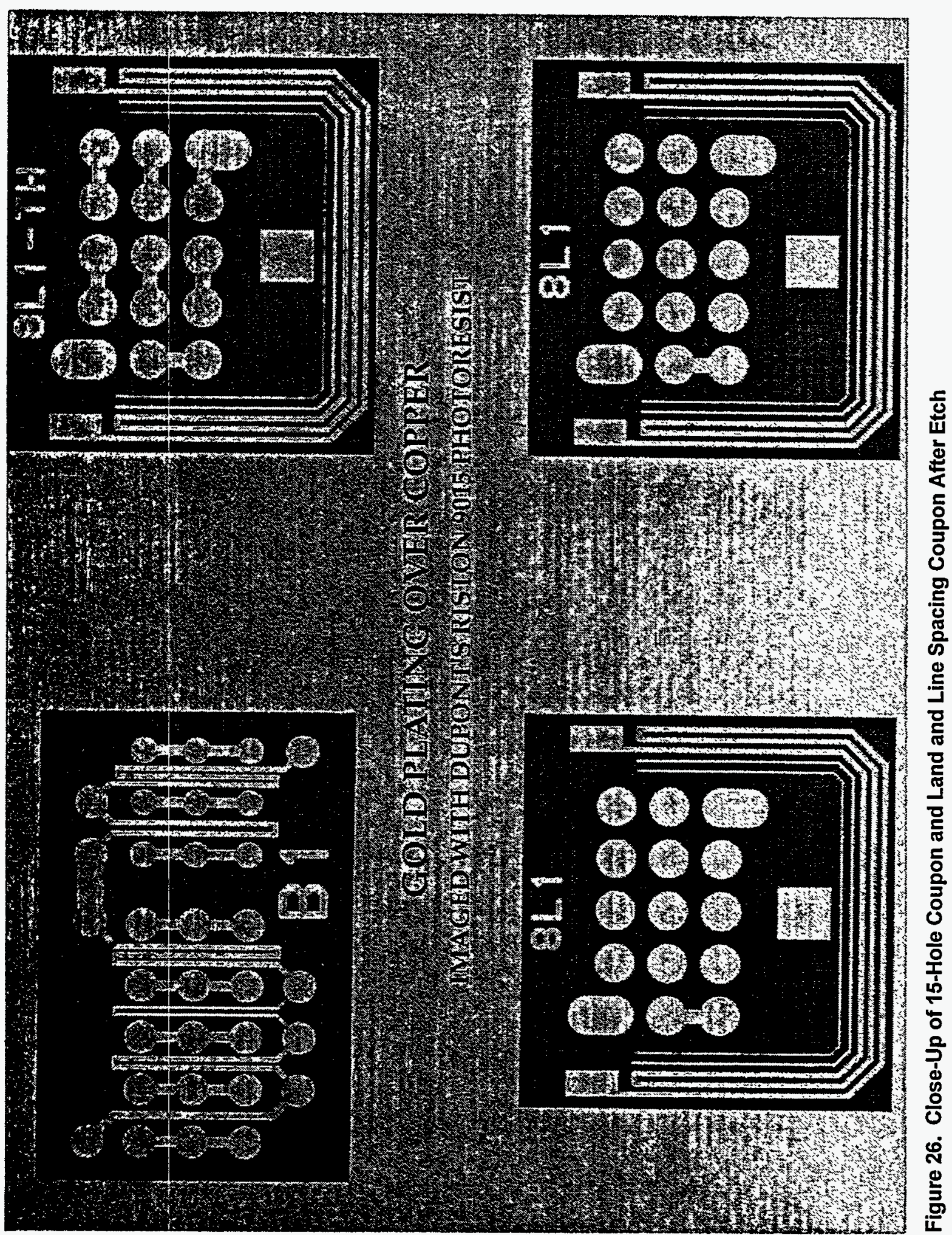




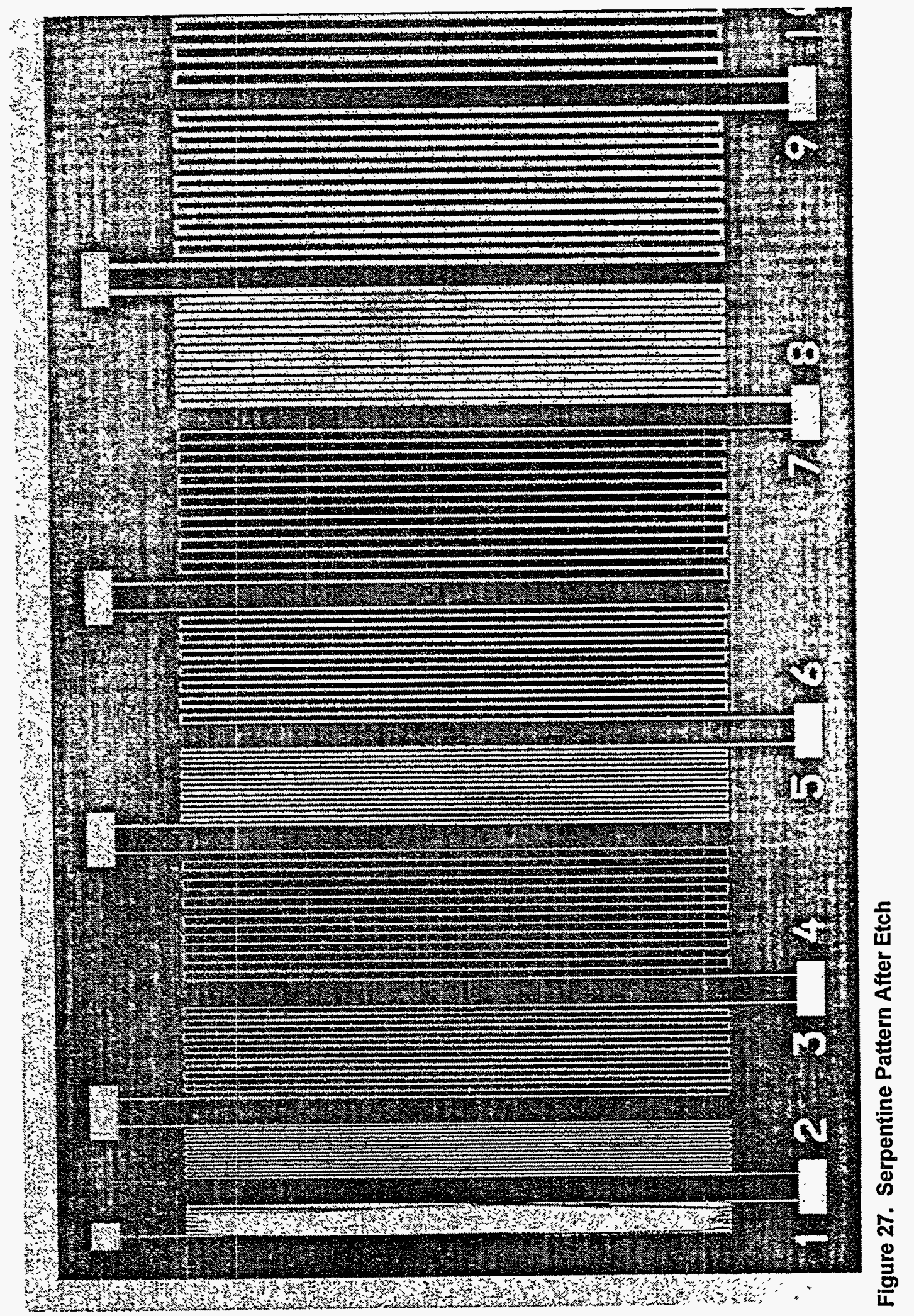


Figure 28 shows the final circuit of panel 10 which shows very good definition of the circuit, but does show some undercutting caused by too long an etching dwell time.
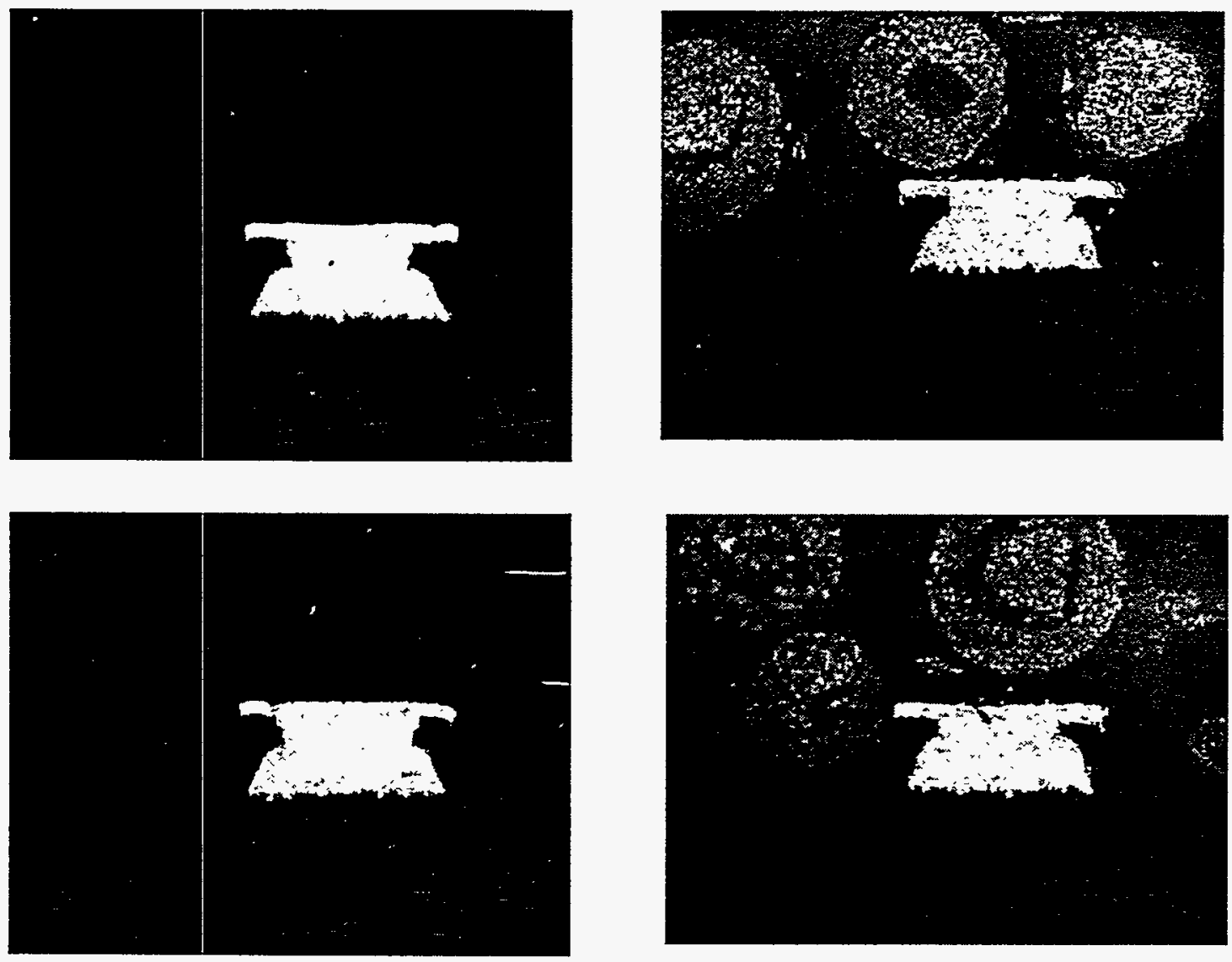

Figure 28. SEM Microphotography of Circuit Processed With DuPont Riston 9015, 2-mil Line Cross Section (acutal measurement approximately 1.3 mils) 
Figure 29 shows a gold-plated circuit.
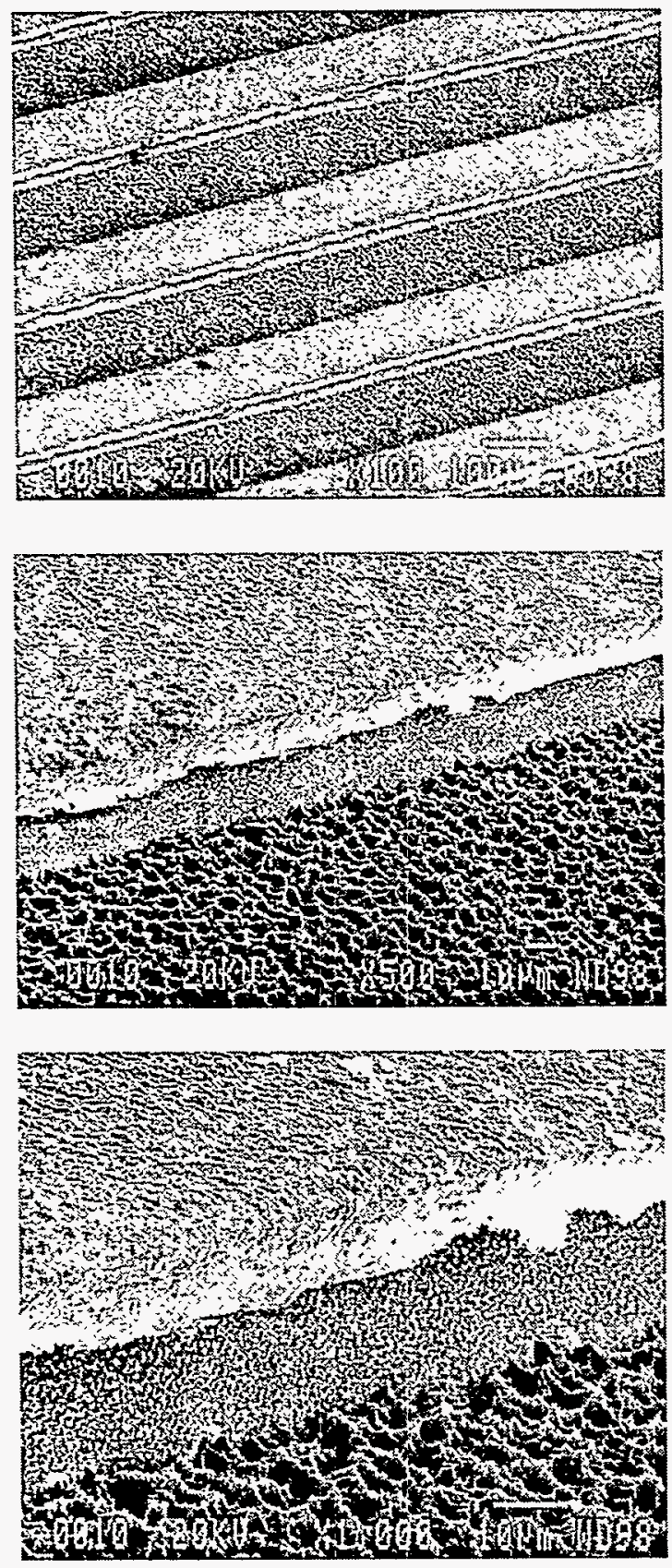

Figure 29. SEM Photomicrographs of Circuits Processed with DuPont Riston 9015, Gold-Plated Circuit After Etch 


\section{Alkaline Etching}

The alkaline etching part of the experiment used a different etch pattern than the KCD capability pattern. In this evaluation, the artwork was a UMPS 5-8 pattern created by the imaging team of the National Center for Manufacturing Sciences (NCMS). The conductor analysis technology artwork is a 10 by 10 array of one-inch-square serpentine patterns $90^{\circ}$ out of phase to evaluate directional processing factors, such as effects of etching lines parallel to the direction of conveyor travel versus etching lines perpendicular to the direction of conveyor travel. This serpentine pattern contains artwork path width sizes of $5,6,7$, and 8 mils. Two panels were processed at each condition and the electrical test data was combined and labeled in Table 10 as a group number (for example, panels 21 and 25 were electrically tested and the test data is combined as group 1).

Table 11. Processing Conditions and Yield Response

\begin{tabular}{|c|c|c|c|c|c|c|c|c|}
\hline \multicolumn{9}{|c|}{ Alkaline Etch - NCMS Artwork, DuPont 9015 Parameters } \\
\hline \multirow{2}{*}{$\begin{array}{l}\text { Panel } \\
\text { No. }\end{array}$} & \multirow{2}{*}{$\begin{array}{l}\text { Group } \\
\text { No. }\end{array}$} & \multirow{2}{*}{$\begin{array}{l}\text { Lam. } \\
\text { Temp. }{ }^{\circ} \mathrm{C}\end{array}$} & \multirow{2}{*}{$\begin{array}{l}\text { Exp. } \\
\text { Set. }\end{array}$} & \multirow[t]{2}{*}{ Develop } & \multicolumn{4}{|c|}{ Conductor Yield \% } \\
\hline & & & & & $5 \mathrm{mil}$ & $6 \mathrm{mil}$ & 7 mil & $8 \mathrm{mil}$ \\
\hline 21,25 & 1 & 110 & 110 & 2.0 & 100.0 & 100.0 & 100.0 & 100.0 \\
\hline 22,23 & 2 & 110 & 80 & 2.0 & 97.00 & 98.00 & 99.50 & 99.50 \\
\hline 24,28 & 3 & 110 & 80 & 2.5 & 99.75 & 99.50 & 99.50 & 99.50 \\
\hline 26,27 & 4 & 110 & 110 & 2.5 & 99.75 & 99.75 & 99.50 & 100.0 \\
\hline 30,31 & 5 & 110 & 110 & 3.25 & 99.25 & 99.25 & 99.25 & 99.50 \\
\hline 29,32 & 6 & 110 & 80 & 3.25 & 99.50 & 99.25 & 99.25 & 99.50 \\
\hline
\end{tabular}

Table 12. Defects for Various Processing Conditions (1-inch Module)

\begin{tabular}{||c|c|r|r|r|r||}
\hline \multicolumn{6}{|c||}{$\begin{array}{l}\text { Alkaline Etch - NCMS Artwork } \\
\text { DuPont } 9015 \text { Parameters }\end{array}$} \\
\hline $\begin{array}{r}\text { Panel } \\
\text { No. }\end{array}$ & $\begin{array}{c}\text { Group } \\
\text { No. }\end{array}$ & \multicolumn{4}{|l|}{$\begin{array}{l}\text { Defects per Million Inches of } \\
\text { Conductor }\end{array}$} \\
\cline { 3 - 6 } & & 5 mil & 6 mil & 7 mil & 8 mil \\
\hline 21,25 & 1 & 0 & 0 & 0 & 0 \\
\hline 22,23 & 2 & 2446 & 1640 & 411 & 415 \\
\hline 24,28 & 3 & 201 & 407 & 411 & 415 \\
\hline 6,27 & 4 & 201 & 203 & 411 & 0 \\
\hline 30,31 & 5 & 403 & 611 & 617 & 415 \\
\hline 29,32 & 6 & 403 & 611 & 617 & 415 \\
\hline
\end{tabular}


A review of this data shows that panels 22 and 23 have significantly higher defects per million inches of conductor in the 5- and 6-mil conductor paths, but still has a conductor yield of $97 \%$ as shown in Table 11.

A review of the entire Processing Sequence for Alkaline etch using Dupont 9015 on the NCMS Conductor Analysis Panel.

1. Copper Pre-image Cleaning - Conveyorized Chemical Cleaning (Table 7)

2. Photoresist Lamination - Hot Roll Laminating of photoresist (Table 11)

3. Photoresist Exposure - Exposing of photoresist (Table 11)

4. Photoresist Develop - Conveyorized Developing of photoresist(Table 11)

5. Copper Etch - Conveyorized Alkaline Etching (Table 13) of copper

6. Photoresist Strip - Conveyorized Stripping of photoresist

Table 13. Alkaline Etch, Ammoniacal Copper Chloride (CE \#54699)

\begin{tabular}{|l|l||}
\hline \hline PARAMETERS & Readings \\
\hline Temperature & 125 \\
\hline Pressure (psi) & $10 / 30$ \\
\hline $\begin{array}{l}\text { Conveyor speed } \\
\text { (in/min) }\end{array}$ & 55 \\
\hline $\mathrm{pH}$ & 7.7 \\
\hline Specific Gravity & 1.195 \\
\hline Copper Thickness & 0.0017 \\
\hline
\end{tabular}

Table 14. Alkaline Etch (Ammoniacal Copper Chloride Solution Limits)

\begin{tabular}{||l|l|l|c||}
\hline Parameters & $\begin{array}{l}\text { Limits } \\
\text { Lower }\end{array}$ & $\begin{array}{l}\text { Limits } \\
\text { Upper }\end{array}$ & $\begin{array}{l}\text { Actual } \\
(3 / 22 / 94)\end{array}$ \\
\hline Copper & 145 & 165 & 145.4 \\
\hline Chloride & 177 & 212 & 211.6 \\
\hline $\mathrm{Ph}$ & 7.6 & 7.8 & 7.7 \\
\hline Conveyor Speed & & & 55 \\
\hline
\end{tabular}

The panels were fabricated in the KCD PWP manufacturing facility and then sent to Sandia National Laboratory, New Mexico, for electrical testing. The line width loss and yield response, as generated by the conductor analysis program, are published in a series of charts in Appendices A through F.

The summary of the alkaline etching evaluation using the NCMS pattern showed a consistent yield of $97 \%$ or better.

- Groups 2 and 3 did have a larger line loss (0.6 to 0.7 mils) than the other groups (0.5 mil line loss).

- Group 3 has a larger standard deviation $(0.2)$ than the other groups $(0.13-0.15$ standard deviation).

- From this evaluation we can conclude that all of the panels were etched with less than 1 mil etch factor and consistent with $0.13-0.2$ standard deviations.

\section{Future Work}

Additional work will be done evaluating the DuPont 9015 for processing chemically machined product etched in ferric chloride rather than the alkaline copper chloride used for PWB fabrication. This evaluation did not evaluate DuPont 9015 on non-copper surfaces - such as nickel alloys, stainless steels, or brass, which are materials etched in the ferric chloride etchant. 


\section{Appendix A}

Group 1 Panels 



\section{GROUP 1}

\section{Conductor Yield vs Nominal Conductor Width}

TM1 \& TM2 Sides

\begin{tabular}{|c|c|c|r|r|r|r|r|r|}
\hline $\begin{array}{c}\text { Artwork } \\
\text { Feature } \\
\begin{array}{c}\text { Size } \\
\text { (mils) }\end{array}\end{array}$ & \multicolumn{5}{|c|}{ Total Number of } & $\begin{array}{c}\text { Conductor } \\
\text { Yield } \\
(\%)\end{array}$ & DEMIS \\
\cline { 2 - 9 } & Lines & Spaces & Opens & Shorts & Good & Bad & \\
\hline \hline & & & & & & & & \\
5 & 400 & 400 & 0 & 0 & 400 & 0 & 100.00 & 0 \\
6 & 400 & 400 & 0 & 0 & 400 & 0 & 100.00 & 0 \\
7 & 400 & 400 & 0 & 0 & 400 & 0 & 100.00 & 0 \\
8 & 400 & 0 & 0 & 0 & 400 & 0 & 100.00 & 0 \\
\hline
\end{tabular}

DEMIS = Defects per Million Inches of Conductor 
Capability Performance Index for $\pm 20 \%$ Controlled Conductor Width

Without Artwork Compensation

Conductor Width and Height Calculated from Electrical Resistance Measurements

\begin{tabular}{|c|c|c|c|c|c|c|c|c|c|c|}
\hline \multirow{2}{*}{$\begin{array}{c}\text { Artwork } \\
\text { Feature } \\
\text { Size } \\
\text { (mils) }\end{array}$} & \multirow{2}{*}{$\begin{array}{c}\text { Target } \\
\text { Conductor } \\
\text { Width } \\
\text { (mils) }\end{array}$} & \multirow{2}{*}{$\begin{array}{c}\text { Number } \\
\text { of } \\
\text { Lines }\end{array}$} & \multicolumn{6}{|c|}{ Calculated Conductor Width (mils) } & \multicolumn{2}{|c|}{ Control Indices } \\
\hline & & & Min & Max & Mean & $\sigma$ & LSL & USL & $\mathrm{Cp}$ & Cpk \\
\hline $\begin{array}{l}5 \\
6 \\
7 \\
8\end{array}$ & $\begin{array}{l}5.0 \\
6.0 \\
7.0 \\
8.0\end{array}$ & $\begin{array}{l}398 \\
398 \\
398 \\
398\end{array}$ & $\begin{array}{l}4.16 \\
5.12 \\
6.10 \\
7.17\end{array}$ & $\begin{array}{l}4.89 \\
5.94 \\
7.03 \\
7.92\end{array}$ & $\begin{array}{l}4.48 \\
5.45 \\
6.47 \\
7.47\end{array}$ & $\begin{array}{l}0.130 \\
0.149 \\
0.152 \\
0.130\end{array}$ & $\begin{array}{l}4.00 \\
4.80 \\
5.60 \\
6.40\end{array}$ & $\begin{array}{l}6.00 \\
7.20 \\
8.40 \\
9.60\end{array}$ & $\begin{array}{l}2.56 \\
2.69 \\
3.07 \\
4.09\end{array}$ & $\begin{array}{l}1.22 \\
1.45 \\
1.90 \\
2.73\end{array}$ \\
\hline \multirow{2}{*}{$\begin{array}{l}\text { Nominal } \\
\text { Copper } \\
\text { Thickness } \\
\text { (mils) }\end{array}$} & \multirow{2}{*}{$\begin{array}{c}\text { Target } \\
\text { Conductor } \\
\text { Height } \\
\text { (mils) }\end{array}$} & \multirow{2}{*}{$\begin{array}{c}\text { Number } \\
\text { of } \\
\text { Modules }\end{array}$} & \multicolumn{6}{|c|}{ Calculated Conductor Height (mils) } & \multicolumn{2}{|c|}{ Control Indices } \\
\hline & & & Min & Max & Mean & $\sigma$ & LSL & USL & $\mathrm{Cp}$ & Cpk \\
\hline 1.40 & 1.20 & 398 & 1.12 & 1.34 & 1.24 & 0.031 & 0.96 & 1.44 & 2.58 & 2.10 \\
\hline
\end{tabular}

LSL $=$ Lower Specification Limit

USL $=$ Upper Specification Limit

Cp = Capability Potential Index

Cpk = Capability Performance Index

TM1 \& TM2 Sides

CATS Version 2.3

Jw200a.mm

8:32:35 July 19, 1994

Cor $=0.997$

$\mathrm{RHO}=2.00$ 
Appendix B

Group 2 Panels 


\section{GROUP 2}

Conductor Yield vs Nominal Conductor Width

TM1 \& TM2 Sides

\begin{tabular}{|c|c|c|c|c|c|c|c|c|}
\hline \multirow{2}{*}{$\begin{array}{c}\text { Artwork } \\
\text { Feature } \\
\text { Size } \\
\text { (mils) }\end{array}$} & \multicolumn{6}{|c|}{ Total Number of } & \multirow{2}{*}{$\begin{array}{l}\text { Conductor } \\
\text { Yield } \\
(\%)\end{array}$} & \multirow{2}{*}{ DEMIS } \\
\hline & Lines & Spaces & Opens & Shorts & Good & Bad & & \\
\hline $\begin{array}{l}5 \\
6 \\
7 \\
8\end{array}$ & $\begin{array}{l}400 \\
400 \\
400 \\
400\end{array}$ & $\begin{array}{r}400 \\
400 \\
400 \\
0\end{array}$ & $\begin{array}{l}9 \\
4 \\
1 \\
2\end{array}$ & $\begin{array}{l}3 \\
1 \\
0 \\
0\end{array}$ & $\begin{array}{l}388 \\
392 \\
398 \\
398\end{array}$ & $\begin{array}{r}12 \\
8 \\
2 \\
2\end{array}$ & $\begin{array}{l}97.00 \\
98.00 \\
99.50 \\
99.50\end{array}$ & $\begin{array}{r}2446 \\
1640 \\
411 \\
415\end{array}$ \\
\hline
\end{tabular}

DEMIS = Defects per Million Inches of Conductor

CATS Version 2.3 
Capability Performance Index for $\pm 20 \%$ Controlled Conductor Width Without Artwork Compensation

Conductor Width and Height Calculated from Electrical Resistance Measurements

\begin{tabular}{|c|c|c|c|c|c|c|c|c|c|c|}
\hline \multirow{2}{*}{$\begin{array}{c}\text { Artwork } \\
\text { Feature } \\
\text { Size } \\
\text { (mils) }\end{array}$} & \multirow{2}{*}{$\begin{array}{c}\text { Target } \\
\text { Conductor } \\
\text { Width } \\
\text { (mils) }\end{array}$} & \multirow{2}{*}{$\begin{array}{c}\text { Number } \\
\text { of } \\
\text { Lines }\end{array}$} & \multicolumn{6}{|c|}{ Calculated Conductor Width (mils) } & \multicolumn{2}{|c|}{ Control Indices } \\
\hline & & & Min & Max & Mean & $\sigma$ & LSL & USL & $\mathrm{Cp}$ & Cpk \\
\hline $\begin{array}{l}5 \\
6 \\
7 \\
8\end{array}$ & $\begin{array}{l}5.0 \\
6.0 \\
7.0 \\
8.0\end{array}$ & $\begin{array}{l}386 \\
391 \\
393 \\
393\end{array}$ & $\begin{array}{l}3.88 \\
4.80 \\
5.78 \\
6.89\end{array}$ & $\begin{array}{l}4.74 \\
5.72 \\
6.74 \\
7.71\end{array}$ & $\begin{array}{l}4.28 \\
5.24 \\
6.26 \\
7.27\end{array}$ & $\begin{array}{l}0.140 \\
0.153 \\
0.158 \\
0.141\end{array}$ & $\begin{array}{l}4.00 \\
4.80 \\
5.60 \\
6.40\end{array}$ & $\begin{array}{l}6.00 \\
7.20 \\
8.40 \\
9.60\end{array}$ & $\begin{array}{l}2.38 \\
2.62 \\
2.96 \\
3.79\end{array}$ & $\begin{array}{l}0.66 \\
0.95 \\
1.39 \\
2.06\end{array}$ \\
\hline \multirow{2}{*}{$\begin{array}{c}\text { Nominal } \\
\text { Copper } \\
\text { Thickness } \\
\text { (mils) }\end{array}$} & \multirow{2}{*}{$\begin{array}{l}\text { Target } \\
\text { Conductor } \\
\text { Height } \\
\text { (mils) }\end{array}$} & \multirow{2}{*}{$\begin{array}{c}\text { Number } \\
\text { of } \\
\text { Modules }\end{array}$} & \multicolumn{6}{|c|}{ Calculated Conductor Height (mils) } & \multicolumn{2}{|c|}{ Control Indices } \\
\hline & & & Min & $\operatorname{Max}$ & Mean & $\sigma$ & LSL & USL & $\mathrm{Cp}$ & Cpk \\
\hline 1.40 & 1.20 & 393 & 1.14 & 1.35 & 1.26 & 0.030 & 0.96 & 1.44 & 2.71 & 2.04 \\
\hline
\end{tabular}

LSL = Lower Specification Limit

USL $=$ Upper Specification Limit

TM1 \& TM2 Sides

Cpk $=$ Capability Performance Index

CATS Version 2.3 sw200a.mm 8:34:54 July 19, 1994 


\section{GROUP 2}

Calculated Conductor Width \& Control Indices vs Target Feature Size with $20 \%$ Specification Limits and no Artwork Compensation

TM1 \& TM2 Sides

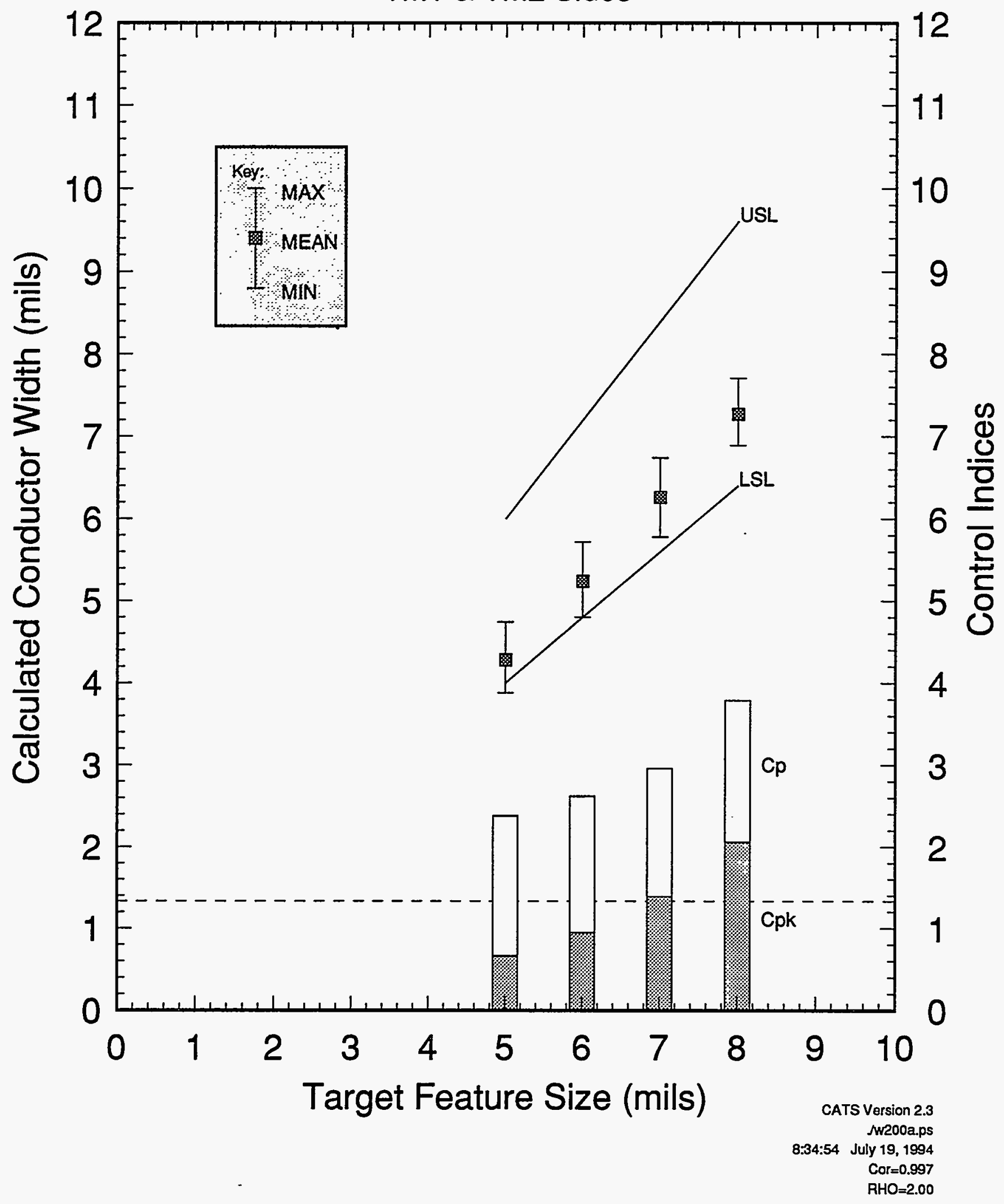


Appendix C

Group 3 Panels 


\section{GROUP 3}

Conductor Yield vs Nominal Conductor Width

TM1 \&. TM2 Sides

\begin{tabular}{|c|c|c|c|c|c|c|c|c|}
\hline \multirow{2}{*}{$\begin{array}{c}\text { Artwork } \\
\text { Feature } \\
\text { Size } \\
\text { (mils) }\end{array}$} & \multicolumn{6}{|c|}{ Total Number of } & \multirow{2}{*}{$\begin{array}{l}\text { Conductor } \\
\text { Yield } \\
(\%)\end{array}$} & \multirow{2}{*}{ DEMIS } \\
\hline & Lines & Spaces & Opens & Shorts & Good & Bad & & \\
\hline $\begin{array}{l}5 \\
6 \\
7 \\
8\end{array}$ & $\begin{array}{l}400 \\
400 \\
400 \\
400\end{array}$ & $\begin{array}{r}400 \\
400 \\
400 \\
0\end{array}$ & $\begin{array}{l}0 \\
0 \\
0 \\
0\end{array}$ & $\begin{array}{l}1 \\
2 \\
2 \\
0\end{array}$ & $\begin{array}{l}399 \\
398 \\
398 \\
398\end{array}$ & $\begin{array}{l}1 \\
2 \\
2 \\
2\end{array}$ & $\begin{array}{l}99.75 \\
99.50 \\
99.50 \\
99.50\end{array}$ & $\begin{array}{l}201 \\
407 \\
411 \\
415\end{array}$ \\
\hline
\end{tabular}

DEMIS $=$ Defects per Million Inches of Conductor 


\section{GROUP 3}

Capability Performance Index for $\pm 20 \%$ Controlled Conductor Width

Without Artwork Compensation

Conductor Width and Height Calculated from Electrical Resistance Measurements

\begin{tabular}{|c|c|c|c|c|c|c|c|c|c|c|}
\hline \multirow{2}{*}{$\begin{array}{c}\text { Artwork } \\
\text { Feature } \\
\text { Size } \\
\text { (mils) }\end{array}$} & \multirow{2}{*}{$\begin{array}{l}\text { Target } \\
\text { Conductor } \\
\text { Width } \\
\text { (mils) }\end{array}$} & \multirow{2}{*}{$\begin{array}{c}\text { Number } \\
\text { of } \\
\text { Lines }\end{array}$} & \multicolumn{6}{|c|}{ Calculated Conductor Width (mils) } & \multicolumn{2}{|c|}{ Control Indices } \\
\hline & & & Min & Max & Mean & $\sigma$ & LSL & USL & $\mathrm{Cp}$ & Cpk \\
\hline $\begin{array}{l}5 \\
6 \\
7 \\
8\end{array}$ & $\begin{array}{l}5.0 \\
6.0 \\
7.0 \\
8.0\end{array}$ & $\begin{array}{l}397 \\
397 \\
397 \\
397\end{array}$ & $\begin{array}{l}3.99 \\
4.86 \\
5.87 \\
6.97\end{array}$ & $\begin{array}{l}5.03 \\
6.09 \\
7.04 \\
8.04\end{array}$ & $\begin{array}{l}4.36 \\
5.33 \\
6.34 \\
7.35\end{array}$ & $\begin{array}{l}0.173 \\
0.190 \\
0.196 \\
0.173\end{array}$ & $\begin{array}{l}4.00 \\
4.80 \\
5.60 \\
6.40\end{array}$ & $\begin{array}{l}6.00 \\
7.20 \\
8.40 \\
9.60\end{array}$ & $\begin{array}{l}1.92 \\
2.11 \\
2.39 \\
3.09\end{array}$ & $\begin{array}{l}0.69 \\
0.92 \\
1.27 \\
1.84\end{array}$ \\
\hline \multirow{2}{*}{$\begin{array}{c}\text { Nominal } \\
\text { Copper } \\
\text { Thickness } \\
\text { (mils) }\end{array}$} & \multirow{2}{*}{$\begin{array}{l}\text { Target } \\
\text { Conductor } \\
\text { Height } \\
\text { (mils) }\end{array}$} & \multirow{2}{*}{$\begin{array}{c}\text { Number } \\
\text { of } \\
\text { Modules }\end{array}$} & \multicolumn{6}{|c|}{ Calculated Conductor Height (mils) } & \multicolumn{2}{|c|}{ Control Indices } \\
\hline & & & Min & Max & Mean & $\sigma$ & LSL & USL & $\mathrm{Cp}$ & Cpk \\
\hline 1.40 & 1.20 & 397 & 1.14 & 1.37 & 1.25 & 0.032 & 0.96 & 1.44 & 2.49 & 1.98 \\
\hline
\end{tabular}

LSL = Lower Specification Limit

USL = Upper Specification Limit

$\begin{aligned} \mathrm{Cp} & =\text { Capability Potential Index } \\ \mathrm{Cpk} & =\text { Capability Performance Index }\end{aligned}$

TM1 \& TM2 Sides

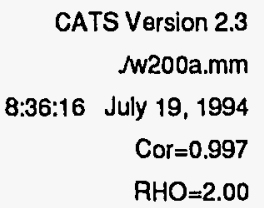




\section{GROUP 3}

Calculated Conductor Width \& Control Indices vs Target Feature Size with $20 \%$ Specification Limits and no Artwork Compensation

TM1 \& TM2 Sides

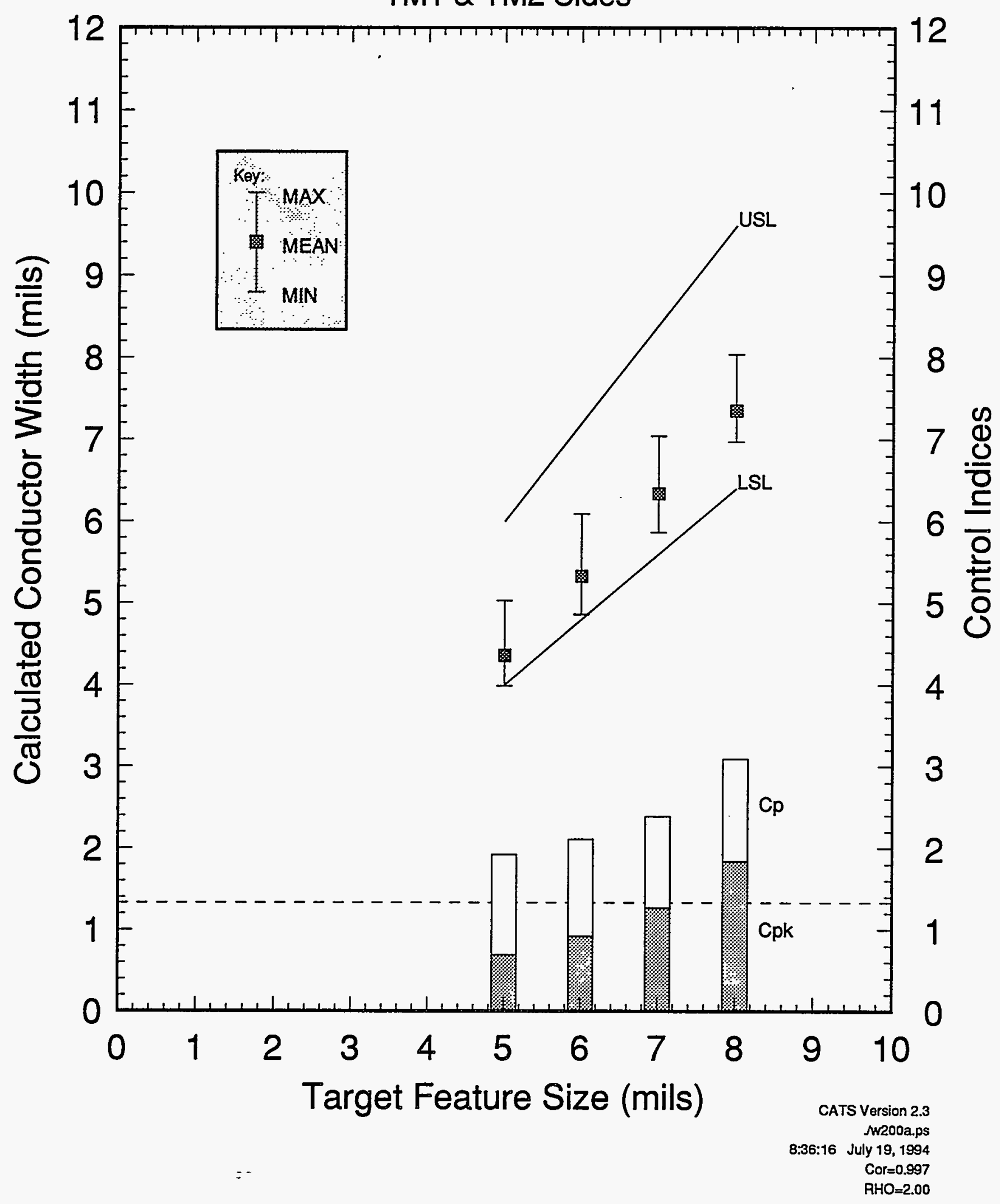





\section{Appendix D}

\section{Group 4 Panels}





\section{GROUP 4}

\section{Conductor Yield vs Nominal Conductor Width}

TM1 \& TM2 Sides

\begin{tabular}{|c|c|c|c|c|c|c|c|c|}
\hline \multirow{2}{*}{$\begin{array}{c}\text { Artwork } \\
\text { Feature } \\
\text { Size } \\
\text { (mils) }\end{array}$} & \multicolumn{6}{|c|}{ Total Number of } & \multirow{2}{*}{$\begin{array}{l}\text { Conductor } \\
\text { Yield } \\
(\%)\end{array}$} & \multirow{2}{*}{ DEMIS } \\
\hline & Lines & Spaces & Opens & Shorts & Good & Bad & & \\
\hline $\begin{array}{l}5 \\
6 \\
7 \\
8\end{array}$ & $\begin{array}{l}400 \\
400 \\
400 \\
400\end{array}$ & $\begin{array}{r}400 \\
400 \\
400 \\
0\end{array}$ & $\begin{array}{l}1 \\
1 \\
2 \\
0\end{array}$ & $\begin{array}{l}0 \\
0 \\
0 \\
0\end{array}$ & $\begin{array}{l}399 \\
399 \\
398 \\
400\end{array}$ & $\begin{array}{l}1 \\
1 \\
2 \\
0\end{array}$ & $\begin{array}{r}99.75 \\
99.75 \\
99.50 \\
100.00\end{array}$ & $\begin{array}{r}201 \\
203 \\
411 \\
0\end{array}$ \\
\hline
\end{tabular}

DEMIS $=$ Defects per Million Inches of Conductor 


\section{GROUP 4}

Capability Performance Index for $\pm 20 \%$ Controlled Conductor Width

Without Artwork Compensation

Conductor Width and Height Calculated from Electrical Resistance Measurements

\begin{tabular}{|c|c|c|c|c|c|c|c|c|c|c|}
\hline \multirow{2}{*}{$\begin{array}{c}\text { Artwork } \\
\text { Feature } \\
\text { Size } \\
\text { (mils) } \\
\end{array}$} & \multirow{2}{*}{$\begin{array}{l}\text { Target } \\
\text { Conductor } \\
\text { Width } \\
\text { (mils) }\end{array}$} & \multirow{2}{*}{$\begin{array}{c}\text { Number } \\
\text { of } \\
\text { Lines }\end{array}$} & \multicolumn{6}{|c|}{ Calculated Conductor Width (mils) } & \multicolumn{2}{|c|}{ Control Indices } \\
\hline & & & Min & $\operatorname{Max}$ & Mean & $\sigma$ & LSL & USL & Cp & Cpk \\
\hline $\begin{array}{l}5 \\
6 \\
7 \\
8\end{array}$ & $\begin{array}{l}5.0 \\
6.0 \\
7.0 \\
8.0\end{array}$ & $\begin{array}{l}397 \\
398 \\
397 \\
398\end{array}$ & $\begin{array}{l}4.16 \\
5.06 \\
6.08 \\
7.15\end{array}$ & $\begin{array}{l}5.08 \\
6.18 \\
7.16 \\
8.09\end{array}$ & $\begin{array}{l}4.48 \\
5.44 \\
6.46 \\
7.48\end{array}$ & $\begin{array}{l}0.132 \\
0.155 \\
0.155 \\
0.134\end{array}$ & $\begin{array}{l}4.00 \\
4.80 \\
5.60 \\
6.40\end{array}$ & $\begin{array}{l}6.00 \\
7.20 \\
8.40 \\
9.60\end{array}$ & $\begin{array}{l}2.53 \\
2.57 \\
3.02 \\
3.98\end{array}$ & $\begin{array}{l}1.22 \\
1.38 \\
1.86 \\
2.67\end{array}$ \\
\hline \multirow{2}{*}{$\begin{array}{c}\text { Nominal } \\
\text { Copper } \\
\text { Thickness } \\
\text { (mils) }\end{array}$} & \multirow{2}{*}{$\begin{array}{c}\text { Target } \\
\text { Conductor } \\
\text { Height } \\
\text { (mils) }\end{array}$} & \multirow{2}{*}{$\begin{array}{c}\text { Number } \\
\text { of } \\
\text { Modules }\end{array}$} & \multicolumn{6}{|c|}{ Calculated Conductor Height (mils) } & \multicolumn{2}{|c|}{ Control Indices } \\
\hline & & & Min & $\operatorname{Max}$ & Mean & $\sigma$ & LSL & USL & $\mathrm{Cp}$ & Cpk \\
\hline 1.40 & 1.20 & 398 & 1.14 & 1.32 & 1.24 & 0.032 & 0.96 & 1.44 & 2.51 & 2.10 \\
\hline
\end{tabular}

LSL = Lower Specification Limit

USL $=$ Upper Specification Limit

TM1 \& TM2 Sides

Cpk $=$ Capability Performance Index

CATS Version 2.3

sw200a.mm

8:37:44 July 19, 1994

Cor $=0.997$

$\mathrm{RHO}=2.00$ 
Calculated Conductor Width (mils)

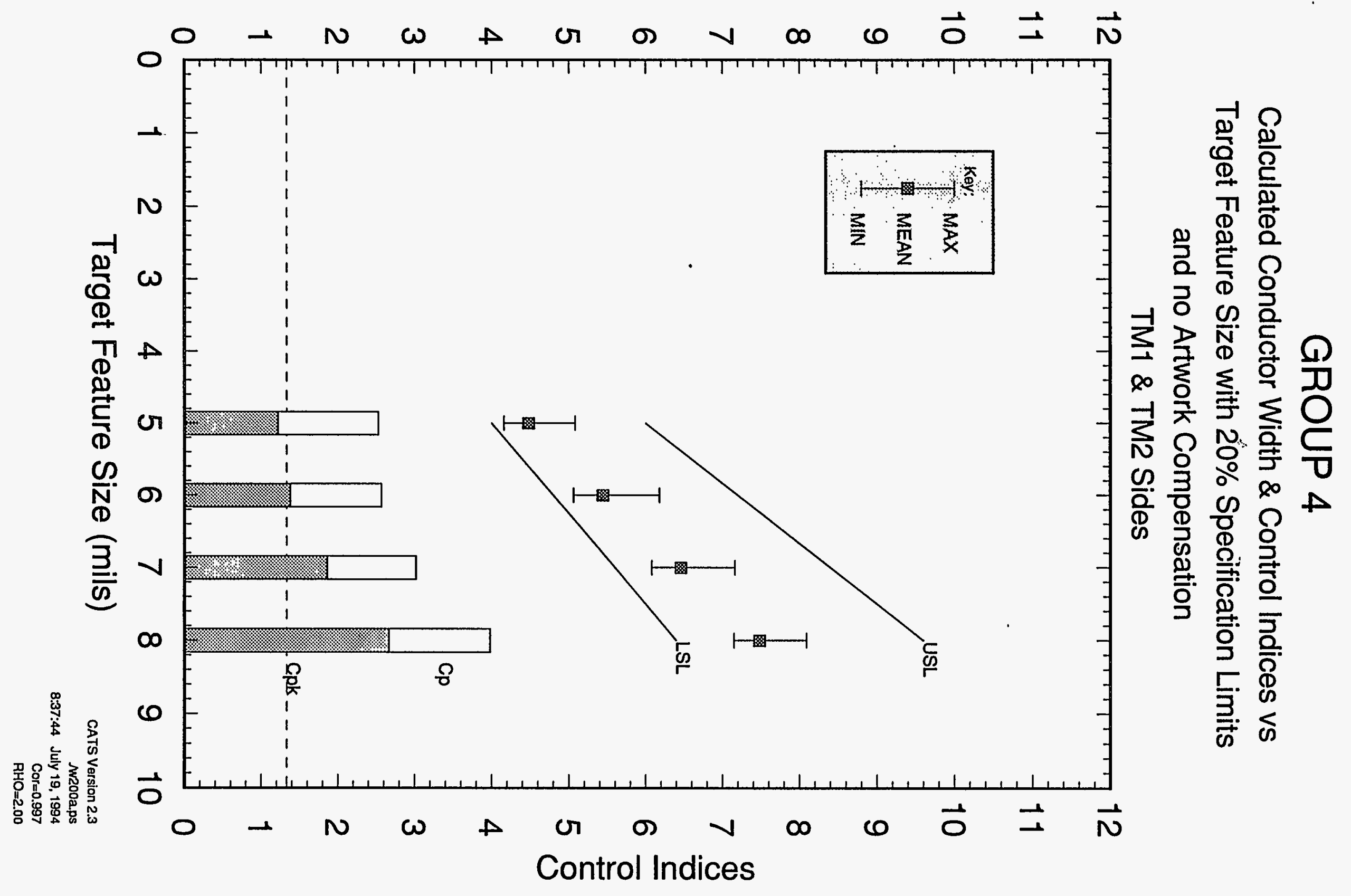





\section{Appendix E}

Group 5 Panels 



\section{GROUP 5}

Conductor Yield vs Nominal Conductor Width

TM1 \& TM2 Sides

\begin{tabular}{|c|c|c|r|r|r|r|r|r|}
\hline $\begin{array}{c}\text { Artwork } \\
\text { Feature } \\
\begin{array}{c}\text { Size } \\
\text { (mils) }\end{array}\end{array}$ & \multicolumn{6}{|c|}{ Total Number of } & $\begin{array}{c}\text { Conductor } \\
\text { Yield } \\
(\%)\end{array}$ & DEMIS \\
\cline { 2 - 8 } & Lines & Spaces & Opens & Shorts & Good & Bad & & \\
\hline \hline & & & & & & & & \\
5 & 400 & 400 & 0 & 2 & 398 & 2 & 99.50 & 403 \\
6 & 400 & 400 & 0 & 2 & 397 & 3 & 99.25 & 611 \\
7 & 400 & 400 & 0 & 2 & 397 & 3 & 99.25 & 617 \\
8 & 400 & 0 & 0 & 0 & 398 & 2 & 99.50 & 415 \\
\hline
\end{tabular}

DEMIS = Defects per Million Inches of Conductor 
GROUP 5

Capability Performance Index for $\pm 20 \%$ Controlled Conductor Width Without Artwork Compensation

Conductor Width and Height Calculated from Electrical Resistance Measurements

\begin{tabular}{|c|c|c|c|c|c|c|c|c|c|c|}
\hline \multirow{2}{*}{$\begin{array}{c}\text { Artwork } \\
\text { Feature } \\
\text { Size } \\
\text { (mils) } \\
\end{array}$} & \multirow{2}{*}{$\begin{array}{l}\text { Target } \\
\text { Conductor } \\
\text { Width } \\
\text { (mils) }\end{array}$} & \multirow{2}{*}{$\begin{array}{c}\text { Number } \\
\text { of } \\
\text { Lines }\end{array}$} & \multicolumn{6}{|c|}{ Calculated Conductor Width (mils) } & \multicolumn{2}{|c|}{ Control Indices } \\
\hline & & & Min & Max & Mean & $\sigma$ & LSL & USL & $\mathrm{Cp}$ & Cpk \\
\hline $\begin{array}{l}5 \\
6 \\
7 \\
8\end{array}$ & $\begin{array}{l}5.0 \\
6.0 \\
7.0 \\
8.0\end{array}$ & $\begin{array}{l}395 \\
395 \\
395 \\
395\end{array}$ & $\begin{array}{l}4.17 \\
5.04 \\
6.09 \\
7.14\end{array}$ & $\begin{array}{l}4.94 \\
5.95 \\
6.95 \\
7.95\end{array}$ & $\begin{array}{l}4.54 \\
5.50 \\
6.52 \\
7.53\end{array}$ & $\begin{array}{l}0.130 \\
0.153 \\
0.154 \\
0.132\end{array}$ & $\begin{array}{l}4.00 \\
4.80 \\
5.60 \\
6.40\end{array}$ & $\begin{array}{l}6.00 \\
7.20 \\
8.40 \\
9.60\end{array}$ & $\begin{array}{l}2.56 \\
2.61 \\
3.02 \\
4.04\end{array}$ & $\begin{array}{l}1.38 \\
1.52 \\
1.99 \\
2.86\end{array}$ \\
\hline \multirow{2}{*}{$\begin{array}{l}\text { Nominal } \\
\text { Copper } \\
\text { Thickness } \\
\text { (mils) }\end{array}$} & \multirow{2}{*}{$\begin{array}{c}\text { Target } \\
\text { Conductor } \\
\text { Height } \\
\text { (mils) }\end{array}$} & \multirow{2}{*}{$\begin{array}{c}\text { Number } \\
\text { of } \\
\text { Modules }\end{array}$} & \multicolumn{6}{|c|}{ Calculated Conductor Height (mils) } & \multicolumn{2}{|c|}{ Control Indices } \\
\hline & & & Min & $\operatorname{Max}$ & Mean & $\sigma$ & LSL & USL & $\mathrm{Cp}$ & Cpk \\
\hline 1.40 & 1.20 & 395 & 1.16 & 1.34 & 1.26 & 0.035 & 0.96 & 1.44 & 2.28 & 1.76 \\
\hline
\end{tabular}

LSL = Lower Specification Limit

USL = Upper Specification Limit

Cpk $=$ Capability Performance Index

TM1 \& TM2 Sides

CATS Version 2.3 sw200a.mm

8:38:43 July 19, 1994 


\section{GROUP 5}

Calculated Conductor Width \& Control Indices vs Target Feature Size with $20 \%$ Specification Limits and no Artwork Compensation

TM1 \& TM2 Sides

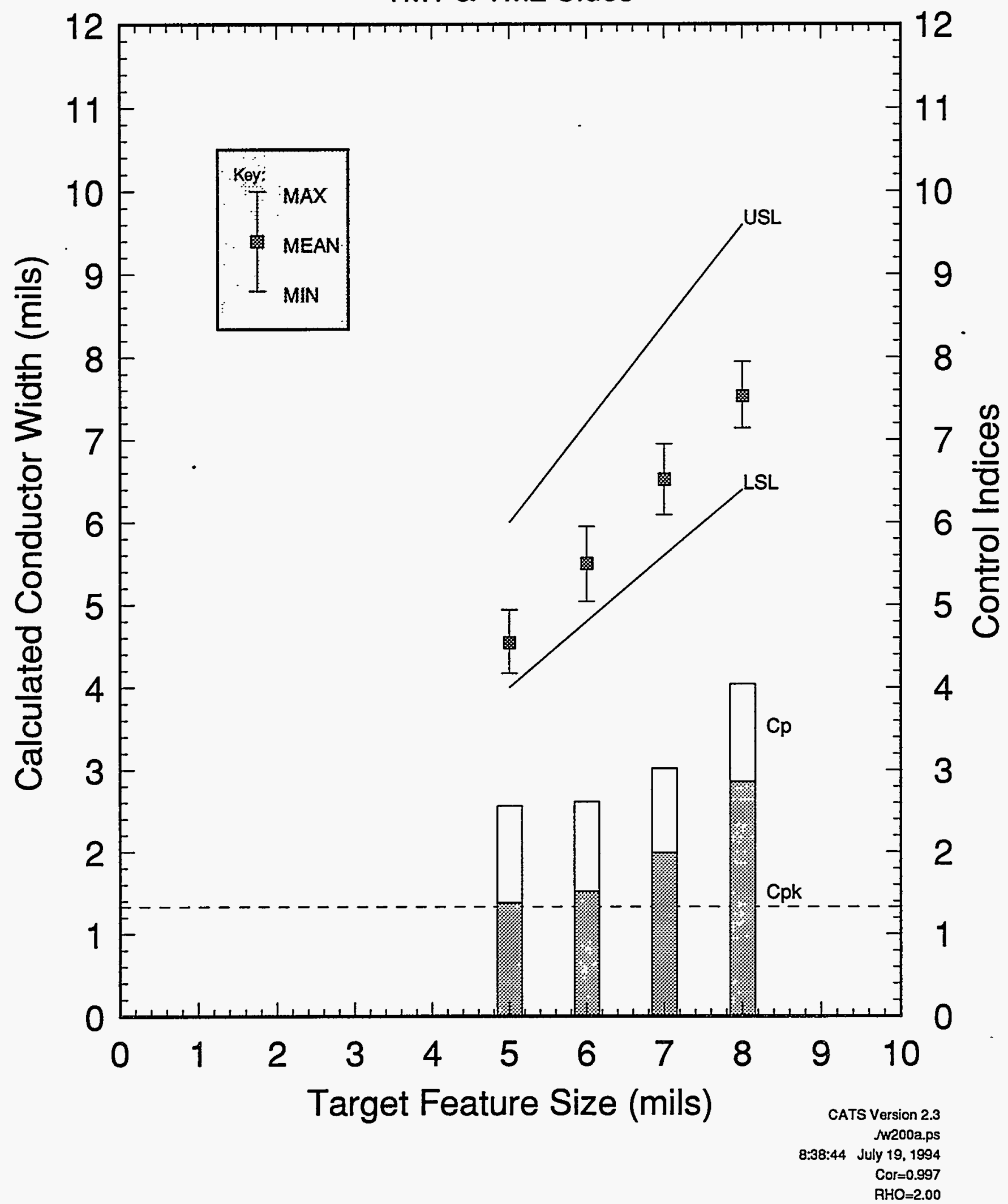


- 


\section{Appendix $F$}

\section{Group 6 Panels}





\section{GROUP 6}

Conductor Yield vs Nominal Conductor Width

TM1 \& TM2 Sides

\begin{tabular}{|c|c|c|c|c|c|c|c|c|}
\hline \multirow{2}{*}{$\begin{array}{c}\text { Artwork } \\
\text { Feature } \\
\text { Size } \\
\text { (mils) }\end{array}$} & \multicolumn{6}{|c|}{ Total Number of } & \multirow{2}{*}{$\begin{array}{l}\text { Conductor } \\
\text { Yield } \\
(\%)\end{array}$} & \multirow{2}{*}{ DEMIS } \\
\hline & Lines & Spaces & Opens & Shorts & Good & Bad & & \\
\hline $\begin{array}{l}5 \\
6 \\
7 \\
8\end{array}$ & $\begin{array}{l}400 \\
400 \\
400 \\
400\end{array}$ & $\begin{array}{r}400 \\
400 \\
400 \\
0\end{array}$ & $\begin{array}{l}0 \\
0 \\
0 \\
0\end{array}$ & $\begin{array}{l}2 \\
2 \\
2 \\
0\end{array}$ & $\begin{array}{l}398 \\
397 \\
397 \\
398\end{array}$ & $\begin{array}{l}2 \\
3 \\
3 \\
2\end{array}$ & $\begin{array}{l}99.50 \\
99.25 \\
99.25 \\
99.50\end{array}$ & $\begin{array}{l}403 \\
611 \\
617 \\
415\end{array}$ \\
\hline
\end{tabular}

DEMIS = Defects per Million Inches of Conductor 


\section{GROUP 6}

Capability Performance Index for $\pm 20 \%$ Controlled Conductor Width

Without Artwork Compensation

Conductor Width and Height Calculated from Electrical Resistance Measurements

\begin{tabular}{|c|c|c|c|c|c|c|c|c|c|c|}
\hline \multirow{2}{*}{$\begin{array}{c}\text { Artwork } \\
\text { Feature } \\
\text { Size } \\
\text { (mils) }\end{array}$} & \multirow{2}{*}{$\begin{array}{l}\text { Target } \\
\text { Conductor } \\
\text { Width } \\
\text { (mils) }\end{array}$} & \multirow{2}{*}{$\begin{array}{c}\text { Number } \\
\text { of } \\
\text { Lines }\end{array}$} & \multicolumn{6}{|c|}{ Calculated Conductor Width (mils) } & \multicolumn{2}{|c|}{ Control Indices } \\
\hline & & & Min & Max & Mean & $\sigma$ & LSL & USL & $\mathrm{Cp}$ & Cpk \\
\hline $\begin{array}{l}5 \\
6 \\
7 \\
8\end{array}$ & $\begin{array}{l}5.0 \\
6.0 \\
7.0 \\
8.0\end{array}$ & $\begin{array}{l}395 \\
395 \\
395 \\
395\end{array}$ & $\begin{array}{l}4.17 \\
5.04 \\
6.09 \\
7.14\end{array}$ & $\begin{array}{l}4.94 \\
5.95 \\
6.95 \\
7.95\end{array}$ & $\begin{array}{l}4.54 \\
5.50 \\
6.52 \\
7.53\end{array}$ & $\begin{array}{l}0.130 \\
0.153 \\
0.154 \\
0.132\end{array}$ & $\begin{array}{l}4.00 \\
4.80 \\
5.60 \\
6.40\end{array}$ & $\begin{array}{l}6.00 \\
7.20 \\
8.40 \\
9.60\end{array}$ & $\begin{array}{l}2.56 \\
2.61 \\
3.02 \\
4.04\end{array}$ & $\begin{array}{l}1.38 \\
1.52 \\
1.99 \\
2.86\end{array}$ \\
\hline \multirow{2}{*}{$\begin{array}{c}\text { Nominal } \\
\text { Copper } \\
\text { Thickness } \\
\text { (mils) }\end{array}$} & \multirow{2}{*}{$\begin{array}{c}\text { Target } \\
\text { Conductor } \\
\text { Height } \\
\text { (mils) }\end{array}$} & \multirow{2}{*}{$\begin{array}{c}\text { Number } \\
\text { of } \\
\text { Modules }\end{array}$} & \multicolumn{6}{|c|}{ Calculated Conductor Height (mils) } & \multicolumn{2}{|c|}{ Control Indices } \\
\hline & & & Min & Max & Mean & $\sigma$ & LSL & USL & $\mathrm{Cp}$ & Cpk \\
\hline 1.40 & 1.20 & 395 & 1.16 & 1.34 & 1.26 & 0.035 & 0.96 & 1.44 & 2.28 & 1.76 \\
\hline
\end{tabular}

LSL = Lower Specification Limit

TM1 \& TM2 Sides

S $=$ pper Specification Limit

Cpk = Capability Performance Index

CATS Version 2.3 


\section{GROUP 6}

Calculated Conductor Width \& Control Indices vs

Target Feature Size with 20\% Specification Limits

and no Artwork Compensation

TM1 \& TM2 Sides

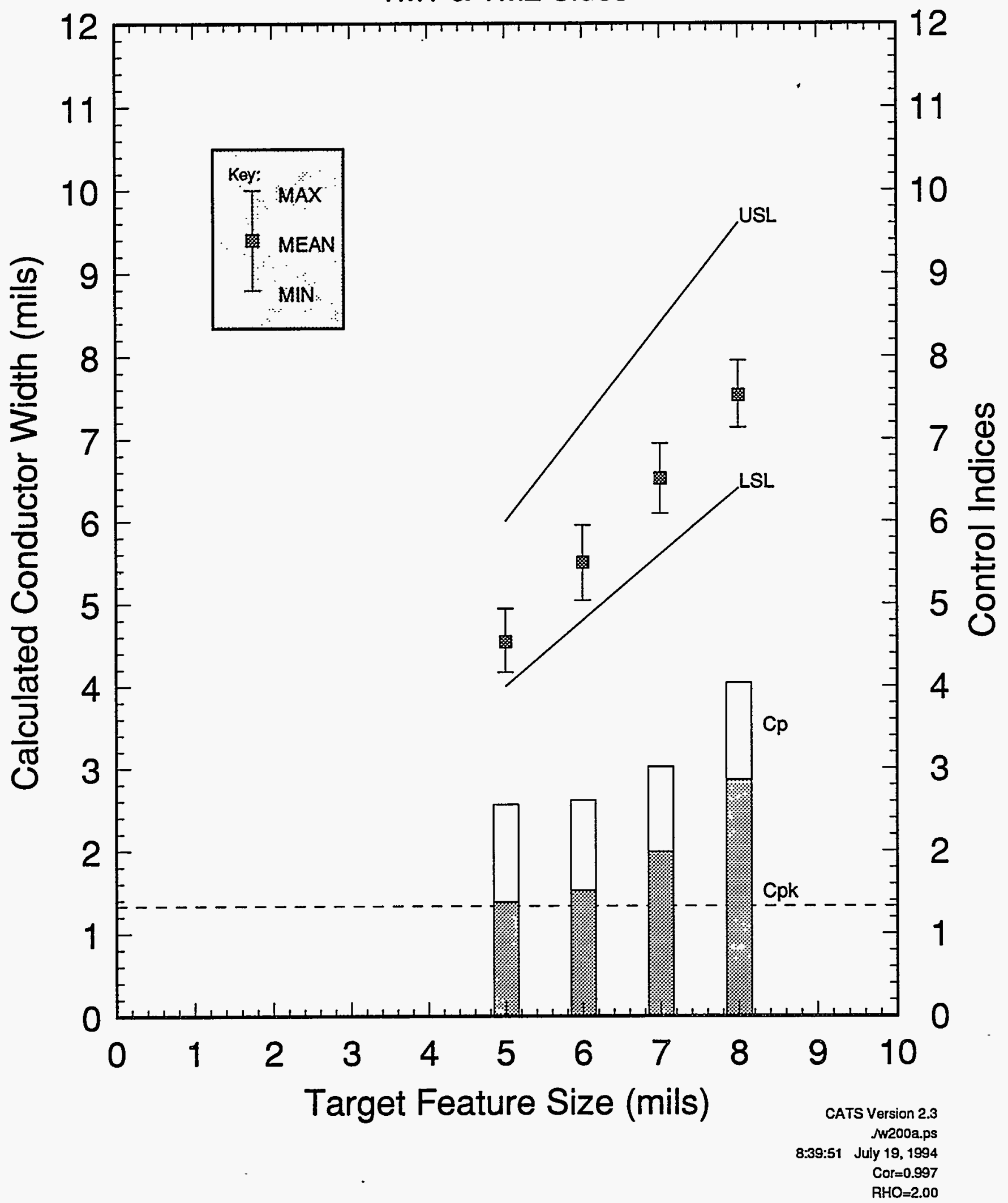

